\title{
Bexiga: cotidiano e trabalho (1906-1931)
}

Bexiga: daily life and work (1906-1931)

\section{SHEILA SCHNECK}

Universidade de São Paulo / São Paulo, SP, Brasil
RESUMO: Resultado da pesquisa realizada para uma tese de doutorado, este trabalho se propõe a conhecer a configuração espacial e humana de um território que em pouco mais de um século resultou no bairro hoje conhecido como Bexiga. Para isso, o delineamento da metodologia e das linhas de trabalho utilizadas para o seu desenvolvimento foi fundamental, na medida em que possibilitou a articulação das diferentes dimensões desse espaço. Em seguida, colocam-se os objetivos propriamente ditos do trabalho. De um lado, precisar o papel desempenhado pelo bairro do Bexiga no processo de transformação urbana ocorrido em São Paulo entre o final do século XIX e início do XX. Naquele momento, ao contrário da cidade colonial, concentrada na colina histórica e aparentemente mais homogênea, a cidade da Primeira República apresentava uma tendência à especialização dos espaços: o perímetro central, com comércio e serviços especializados; e os perímetros, urbano e suburbano, com bairros residenciais destinados às camadas altas, médias e baixas. De outro lado, levando em conta o elemento humano, fundamental para a compreensão do espaço urbano, busca-se também desvendar a sociotopografia e as formas de sociabilidade, assim como de tensões existentes entre os diferentes grupos sociais que vivenciaram o bairro, através da identificação do perfil dos atores sociais predominantes. Dessa maneira, pretende-se desmistificar estereótipos relacionados ao Bexiga como um bairro homogêneo, assumindo como premissa a ideia da diversidade e elucidando as facetas várias de uma área nem exclusivamente italiana, tampouco "encortiçada" e "operária".

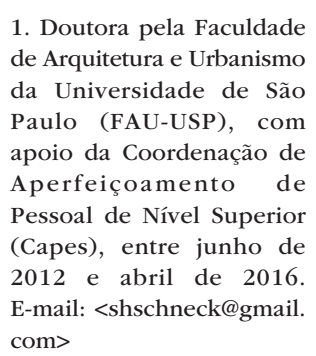

1. Doutora pela Faculdade de Arquitetura e Urbanismo da Universidade de São apoio da Coordenação de Aperfeiçoamento de Pessoal de Nível Superior (Capes), entre junho de E-mail: <shschneck@gmail. com> 
2. Lepetit (2001).

3. Lepetit (2001, p. 213).
PALAVRAS-CHAVE: São Paulo. Urbanização. Bexiga. Funções. Trabalho. Sociedade.

ABSTRACT: Result of the research carried out for the preparation of a doctoral thesis, this work proposes to meet spatial configuration and a human neighborhood along little more than a century resulted in the territory today known as "Bexiga". To do this, the design of the methodology and the work lines used for your development were fundamental, in that it enabled the articulation of the various dimensions of that space. Then there are the actual goals of the job. On the other hand, the role played by the Bexiga in the process of urban transformation occurred in São Paulo, between the late 19th and early 20th centuries. At that time, unlike the colonial city, focusing on historical and Hill apparently more homogeneous, the city of the First Republic showed a tendency towards specialization of spaces: the central perimeter, with trade and specialized services; and the urban and suburban areas with residential neighborhoods for high, medium and low layers. On the other hand, taking into account the human element, central to the understanding of urban space, unravel the sociotopografia and forms of sociability, as well as tensions between different social groups that have experienced the neighborhood, through the identification of profile of prevailing social actors. In this way, it is intended to demystify the stereotypes related to the Bexiga as a homogenous neighborhood, assuming the premise of the idea of diversity and clarifying the various facets of an area not exclusively Italian and either "encortiçada" and "worker".

KEYWORDS: São Paulo. Urbanization. Bexiga. Functions. Job. Society.

\section{INTRODUÇÃO}

título deste trabalho já diz muito acerca de seus objetivos. Trata-se, antes de tudo, de compreender o significado de determinado espaço urbano em relação ao contexto mais amplo em que ele está inserido, a cidade. No entanto, ainda que o objeto de estudo seja o microcosmo de um bairro, qualquer tentativa de compreensão de um espaço destacado do todo tem grandes chances de redundar em visões distorcidas da realidade que se pretende conhecer. Parti de algumas premissas abordadas por Bernard Lepetit. ${ }^{2}$ A primeira se refere à construção de um modelo reduzido do objeto de análise, pois "o conhecimento do todo precede o das partes". ${ }^{3}$ Em sintonia com essa ideia, outra premissa importante do autor se refere à utilização de diferentes escalas no estudo do território, considerando que a escolha de uma dimensão não exclui a importância da outra, já que ambas 
respondem a pontos de vista diferentes, porém complementares. ${ }^{4}$ Neste caso, o pano de fundo do trabalho é dado por um processo comum às duas escalas, a macro e a micro. Sob o ponto de vista da história urbana, a primeira escala fornece as dimensões políticas, econômicas e culturais que incidiram sobre a tessitura material e social do espaço da cidade como um todo, em determinado período. Já a escala micro, ao focar um bairro específico, procura expor de que maneira aquele espaço vivenciou o processo maior, e como os traços que the são peculiares - sua composição étnica, social e material, por exemplo - incidiram sobre a escala macro, num movimento de contínua interação. Assim, para pensar o microcosmo de um bairro é necessário que se lance o olhar em direção ao espaço maior e ao processo que engendrou sua existência para depois retornar ao objeto inicial.

Para o estudioso da história urbana, tão importante quanto apreender o significado do processo de construção do cenário material é compreender as práticas sociais estabelecidas entre os atores que viabilizaram a consolidação do bairro e em que medida suas ações interferiram no meio. Ao privilegiar determinado território, forçosamente aproximamos nosso olhar dos sujeitos que deram feições ao lugar, mesmo que não seja possível alcançar a totalidade dessa ação. Nesse sentido, é necessário pensar questões historiográficas acerca dos diferentes pontos de vista assumidos por quem tem o espaço urbano como objeto, para o que retomo Lepetit:

A questão dos atores dissolve-se no postulado da indiferenciação de identidades culturais partilhadas de que apenas a escala lou seja, a identificação dos limites dos grupos que a partilham) está por determinar. A natureza das relações entre a representação e a ação, embora não explicitada está contida nessa definição. Representação e ação pertencem a esferas separadas: de um lado há normas, valores, categorias que dão sentido ao mundo; e, de outro, comportamentos e atos que os instrumentalizam [...] Por simetria, nessas condições, a ação possui, em relação à representação, o estatuto de sinal ou índice. ${ }^{5}$

Entendo que a afirmação do autor não exclui a esfera das representações da esfera das ações, mas diz, sim, que ambas se complementam. A ação, ao colocar em relevo o comportamento de determinado grupo social, está colocando em evidência a "reação" deste grupo às normas e valores dados pelas mentalidades subjacentes àquele momento histórico. Por outro lado, a escala em que esse movimento se insere associa-se à outra de dimensões mais amplas da mesma realidade, aquela do contexto macro. É como se, por meio de diferentes movimentos intercalados e conectados - ora de aproximação e recuo da lente micro e macroscópica sobre o objeto de estudo a partir da mesma posição, ora mudando a própria posição/perspectiva -, fosse possível obter um conjunto mais coerente da realidade que se pretende compreender.

4. Lepetit (2001, p. 215216).

5. Lepetit (2001, p. 233, grifos meus). 
O território atualmente conhecido como Bexiga é o resultado de um processo político e econômico mais amplo pelo qual passava o país desde a segunda metade do século XIX, com o desenvolvimento da economia cafeeira e a inserção do estado de São Paulo no mercado exportador, envolvendo a Abolição da Escravidão e a substituição dessa mão de obra por aquela imigrante, a instauração da República e a readequação das práticas urbanas de acordo com os parâmetros europeus de urbanização e industrialização. Simultaneamente à entrada de novos atores na cidade, foram tomadas iniciativas em direção do zoneamento e da especialização de usos e funções, explícitos e implícitos na legislação, com o objetivo de adequar a cidade ao novo papel.

Nesse rearranjo, na colina histórica e nas áreas lindeiras se manteve ainda por algum tempo a coexistência de usos residenciais e atividades produtivas, os quais ficaram restritos a pessoas condizentes com o espaço reconstruído ao longo das primeiras décadas do século XX e envolvidas no exercício de atividades distintivas bastante especializadas. Esse foi o caso de serviços como restaurantes, hotéis, cafés, confeitarias, charutarias etc., do comércio de artigos de luxo, de máquinas importadas para lavoura e indústria, de artigos de trabalho para profissionais especializados, além das instituições da administração pública, escritórios e consultórios de profissionais liberais e sedes de instituições financeiras como os bancos. ${ }^{6}$ Assim, foi deslocada do Centro parte das moradias e dos segmentos do comércio de gêneros alimentícios, bem como oficinas, depósitos e fábricas e serviços menos nobres foram em direção dos bairros vizinhos ao perímetro central. Nesse contexto, em função da demanda, surgiram empreendimentos imobiliários de loteamentos destinados a abrigar moradores e atividades produtivas essenciais à cidade em expansão, dando origem a novos bairros, sendo o Bexiga um caso exemplar desse fenômeno.

Embora o objeto deste estudo seja um território determinado, a complexidade da cidade de São Paulo exige que não se perca de vista as demais partes desse todo, pois se trata de um processo em que cada espaço da cidade representou seu papel, o qual ao mesmo tempo é específico e complementar aos demais. Tendo em vista o referencial teórico que privilegia a microescala, o diálogo com autores que abordaram a história da cidade de São Paulo de diferentes pontos de vista foi importante na medida em que forneceu o contraponto e o complemento para a compreensão de meu próprio objeto de trabalho.

A metodologia aqui adotada relaciona-se a uma linha de pesquisa em história da urbanização em interface com a história da cultura material que vem sendo delineada no Museu Paulista da Universidade de São Paulo (MP-USP) por Heloísa Barbuy e na FAU-USP por Beatriz Bueno e seus orientandos.? Tal linha de pesquisa 
em muito se aproxima daquela desenvolvida por Bernard Gauthiez ${ }^{8}$ em seus estudos sobre a cidade de Lyon. Trata-se de uma linha de estudos que privilegia o "grão fino", - lote a lote, o imóvel comum, e a partir dos elementos que compõem 90\% da tessitura urbana reconstitui as lógicas de produção e apropriação social dos espaços.

Para tanto, mobilizei e cruzei dados oriundos de séries documentais variadas - impostos, censos, permissões de construção ou reforma de prédios, permissões para abertura e exercício de negócios, anuários estatísticos, artigos de jornais etc. As informações coletadas nessas fontes geraram tabelas e mapas temáticos georreferenciados, permitindo leituras inusitadas referentes ao processo e às dinâmicas de produção e reprodução social dos espaços, pondo luz nos atores envolvidos na longa duração. Ao investigar fontes documentais que contemplam direta ou indiretamente variadas instâncias da vida urbana na sua dimensão material e cotidiana mais comum - como as permissões de construção e reforma de prédios, atividades profissionais divulgadas nos almanaques, impostos sobre propriedades e atividades produtivas, ocorrências policiais etc. -, é possível visualizar espacialmente um panorama social, profissional e material de outra forma invisível, sem o qual fica difícil historicizar o significado de determinada área para a cidade como um todo.

Em sentido oposto, sobretudo ao verticalizar o olhar, essa linha de trabalho complementa e corrobora certas teses, mas também desmistifica outras delineadas por uma historiografia de perfil mais horizontal e panorâmico com foco mais nos aspectos de conjunto que nas filigranas do prédio comum e das ações individuais corriqueiras.

A São Paulo do século XIX e das primeiras décadas do XX só muito recentemente vem merecendo a atenção de pesquisadores. Em função do seu processo voraz de transformação, arquitetos e urbanistas envolvidos com a docência e as instituições voltadas à preservação do patrimônio histórico recém-constituídas, - Conselho de Defesa do Patrimônio Histórico, Arqueológico, Artístico e Turístico (Condephaat) e o Departamento do Patrimônio Histórico (DPH) - iniciaram o inventário e o paralelo estudo da história dos edifícios e da tessitura que compunha - grosso da urbe paulistana. Casos, principalmente, de Benedito Lima de Toledo, em São Paulo: três cidades em um século; 9 Carlos Lemos, em Cozinhas, etc., Alvenaria Burguesa, Casa paulista: história das moradias anteriores ao ecletismo trazido pelo café e A República ensina a morar (melhor); 10 Nestor Goulart Reis Filho, em Quadro da arquitetura no Brasil, São Paulo e outras cidades, Habitação popular no Brasil: 1880-1920 e São Paulo, Vila, Cidade e Metrópole. "1

A importância desses trabalhos se deve especialmente ao fato de representarem a "primeira geração" a pensar, cada um à sua maneira, arquitetura e cidade como parte de um mesmo processo. De outro lado, simultaneamente ao
8. Cf. Gauthier (2008); Gauthier; Zeller (2014).

9. Toledo (1981).

10. Lemos (1976, 1985, 1999a, 1999b).

11. Reis Filho (1994a, 1994b, 2004a, 2004b). 
12. O Concurso de Monografias sobre a História dos Bairros de São Paulo foi instituído pela Lei $\mathrm{n}^{\circ} 8.248$, de 7 de maio de 1965.

13. Marzola (1979).

14. Homem (2011).

15. Rolnik (2003).

16. Bonduki (1998). trabalho acadêmico, e até como extensão dele, vincularam a preservação do patrimônio edificado à evolução urbana, desempenhando papel relevante na conceituação de políticas preservacionistas. É na perspectiva sistêmica proposta pela linha dos estudos de história da urbanização, desenvolvidos particularmente por Nestor Goulart, que articulei a microescala do Bexiga e dos imóveis à escala da cidade, e desta à Província/Estado e ao mundo industrializado.

Trabalhos que privilegiaram a história de bairros foram os pontos de partida para pensar essa articulação, como as monografias publicadas pelo Arquivo Histórico Municipal (AHM) através de concurso de monografias sobre a História dos Bairros de São Paulo, ${ }^{12}$ entre os quais destaco Bela Vista, de Nádia Marzola, ${ }^{13}$ e Higienópolis: grandeza de um bairro paulistano, de Maria Cecília Naclério Homem. ${ }^{14}$ Nesse último caso, embora a autora analise um espaço ocupado sobretudo pela elite cafeeira e por industriais e famílias estrangeiras influentes, até pelo fato de o estudo abordar um bairro diametralmente oposto ao caráter popular do Bexiga, acredito que a identificação e o contraste das diferenças entre as duas áreas permitam a reflexão sobre o papel complementar que esses espaços representaram no processo urbanizador da cidade de São Paulo em outros tempos.

Nos anos 1980-1990 foram lançados novos trabalhos que ampliaram as perspectivas de análise e compreensão da história da cidade de São Paulo. Tratase daquela que eu chamaria de "segunda geração" de autores que pensaram o espaço urbano sob uma perspectiva mais ampla, identificando as conexões entre as diferentes instâncias da vida pública e privada: legal, política, econômica, social e cultural. Esse é o caso de A cidade e a lei: legislação, política urbana e territórios na cidade de São Paulo, ${ }^{15}$ livro em que Raquel Rolnik analisa como a legislação urbanística, concebida entre as últimas décadas do século XIX e as primeiras do século XX, determinou a forma de ocupação e usos dos espaços urbanos, e como os vínculos entre a municipalidade e os interesses das classes dominantes e da iniciativa privada terminaram por gerar desigualdades sociais definitivas para os destinos de São Paulo. Hoje, as questões colocadas por Rolnik são fundamentais para pensarmos a cidade que temos, pois ao mesmo tempo que auxiliam a compreensão do presente através do passado, impõem novas indagações acerca das mudanças e permanências através do tempo histórico.

Assim como Raquel Rolnik, Nabil Bonduki, em Origens da habitação social no Brasil, 16 faz parte da geração que refletiu sobre as implicações mais profundas das políticas urbanas brasileiras levadas a cabo no decorrer do século XX. Enquanto Rolnik se empenhou na análise dos efeitos de curto e longo prazo das práticas urbanísticas oficiais na consolidação e perpetuação dos territórios "informais" na cidade, Bonduki estendeu suas considerações à questão da habitação popular. 
Sob uma perspectiva multidisciplinar, investigou como, a partir do momento em que a carência de moradias se torna um problema efetivo para o poder público, desde fins do século XIX, gradativamente o Estado passou a interferir na questão habitacional, indiretamente, por meio da legislação urbanística, ou de forma incisiva a partir da Era Vargas, quando passou a intervir no mercado de locação via Lei do Inquilinato, de 1942, e da posterior produção direta de conjuntos habitacionais populares via Institutos de Aposentadoria e Pensões.

Por fim, é importante destacar que, além de identificar a conexão de aspectos pouco considerados até então, os autores supracitados têm o mérito de ser os primeiros a deslocar o foco da produção acadêmica para as implicações sociais das práticas urbanísticas e arquitetônicas.

Nos anos 2000 vemos surgir um conjunto expressivo de novas contribuições para a reflexão sobre a arquitetura nas suas interfaces com o espaço urbano, configurando um terceiro momento da historiografia sobre São Paulo. Destaco a pesquisa de José Eduardo de Assis Lefèvre, De beco a avenida: a história da rua São $L_{i z i z}{ }^{17}$ que pelo estudo de uma área - lote a lote - desvenda lógicas de transformações da própria cidade. Com foco nas terras de propriedade do Brigadeiro Luís Antônio de Souza Queiroz, na Consolação, que deram origem à avenida São Luiz, Lefèvre mostra a partir do século XIX o processo de parcelamento dos lotes e sua posterior venda a terceiros.

Outros estudos igualmente importantes são aqueles de Marisa Midori Deaecto, ${ }^{18}$ Barbuy ${ }^{19}$ e Beatriz Bueno, ${ }^{20}$ com foco nas ações individuais e no processo de produção e uso dos espaços entre meados do século XIX e início do século XX. Marisa Midori, em Comércio e vida urbana na cidade de São Paulo ( $1889-1930$ ), explorou faces do comércio e dos comerciantes na evolução da metrópole, a partir da internacionalização do mercado e da vinculação da economia brasileira ao sistema capitalista com a expansão das redes de troca via exportação do café e importação de produtos industrializados, via desenvolvimento da indústria local (que ao alimentar o comércio local, foi por ele impulsionada), demonstrando a vocação comercial e financeira do Centro da cidade.

Na mesma direção, Heloísa Barbuy, em A Cidade-Exposição: comércio e cosmopolitismo em São Paulo, ${ }^{21}$ elegeu as casas comerciais do Centro de São Paulo como ponto de partida para desenvolver o estudo do microterritório do "Triângulo" do ponto de vista de sua produção material e das mudanças de hábitos e vida urbana ali operados. Na linha dos estudos de história da cultura material, em seu trabalho, a arquitetura e a própria cidade são entendidas como "artefatos" que evocam mentalidades, valores e interesses definidos por grupos sociais em cada momento histórico. Com foco no espaço construído e em suas determinantes
17. Lefèvre (2006).

18. Deaecto (2002).

19. Barbuy (2006).

20. Bueno $(2005,2008$, 2012).

21. Barbuy (2006). 
22. Bueno (2005).

23. Bueno (2008).

24. Marins (2011).

25. Reis Filho (1994a, 1994b, 2004a, 2004b).

26. Toledo (1981).

27. Gennari (2005). legais, a autora desvenda o papel da iniciativa privada na sua produção e uso, com ênfase nesta segunda dimensão, analisando nas ruas XV de Novembro, Direita e São Bento, lote a lote, os diversos tipos de negócios vinculados ao comércio, aos serviços e às novas práticas sociais por eles ensejadas.

Beatriz Bueno, ao espacializar a Décima Urbana de 1809 em São Paulo, ${ }^{22}$ também atentou para o papel das ações da iniciativa privada no processo de transformação da cidade. Em Aspectos do mercado imobiliário em perspectiva histórica: São Paulo (1 809-1950), ${ }^{23}$ a autora analisou a dinâmica de transformação da cidade de São Paulo através de fragmentos, investigando lote a lote os atores sociais envolvidos (proprietários e inquilinos), as tipologias arquitetônicas utilizadas e os usos ali instalados. Além da contribuição metodológica para a tese que originou este trabalho, Bueno abordou ainda um aspecto pouco pensado da história da cidade, ao focalizar o caráter rentista de grande parte das construções em mãos da iniciativa privada desde o período colonial.

Se a maioria dos trabalhos elencados teve como objeto as áreas "nobres" da cidade, das elites, na contramão destaco o ensaio de Paulo Cesar Garcez Marins, Um lugar para as elites: os Campos Elíseos de Glette e Nothmann no imaginário urbano de São Paulo. ${ }^{24}$ Nesse trabalho, o autor, na linha das hipóteses formuladas por Reis Filho, ${ }^{25}$ ressalta a heterogeneidade do conjunto e a diversidade das atividades presentes num bairro supostamente residencial e exclusivo das elites, problematizando a imagem corrente dos Campos Elíseos como um bairro essencialmente aristocrata. Embora sem conexão direta com o Bexiga, nos leva a pensar em que medida bairros como este dependiam do Bexiga para seu abastecimento cotidiano, bem como serviços básicos, algo que os estudos de Benedito Lima de Toledo sobre a Avenida Paulista também permitem imaginar. ${ }^{26}$

Esses trabalhos, em geral, recortam seus estudos no bairro ou área eleita sem problematizar as interfaces e a interdependência com as outras lindeiras. Da mesma forma, os estudos sobre os bairros populares igualmente não têm a preocupação de explorar o papel desses lugares em relação a outras partes da cidade, em geral centrando suas atenções nos seus elementos diacríticos mais evidentes - bairro operário, bairro fabril, bairro aristocrático -, sem todavia questionar a eventual pluralidade de atividades ali existentes.

Nesse sentido, este trabalho sequencia uma linha de investigação que vem gradativamente se afirmando com foco no processo de produção e apropriação de áreas mais pobres da cidade e no papel das camadas médias e baixas da população nesse processo. Esse é o caso de autores como Luciana Alem Gennari, em As casas em série do Brás e da Mooca: um aspecto da constituição da cidade de São Paulo, ${ }^{27}$ 
Maria Luiza Ferreira de Oliveira, em Entre a casa e o armazém: relações sociais e experiência da urbanização, ${ }^{28}$ e Daniel Roche, em $O$ povo de Paris. ${ }^{29}$

A perspectiva adotada por Daniel Roche e Maria Luiza Ferreira de Oliveira, na qual os atores sociais assumem a posição central de uma cena marcada pela transitoriedade, tem muito a ver com a intenção deste trabalho de compreender a tessitura material e social do bairro do Bexiga. $\bigcirc$ mesmo ocorre com relação à metodologia utilizada por eles, em que as expressões materiais possuem um significado importante como documento para a história. Sem a pretensão de "recompor" o exato cenário material do Bexiga nas primeiras décadas do século XX, tenta-se, sim, recuperar algo da relação estabelecida entre o elemento humano e o espaço físico em determinada circunstância, e, quem sabe, a sua própria identidade.

\section{O TERRITÓRIO EM QUESTÃO: (OU) TRÊS BEXIGAS EM UM}

De acordo com o projeto elaborado pelo engenheiro Fernando de Albuquerque (Figura 1), os limites do loteamento original do Bexiga, ainda que mal situados quanto ao posicionamento norte-sul da cidade, são bem precisos.

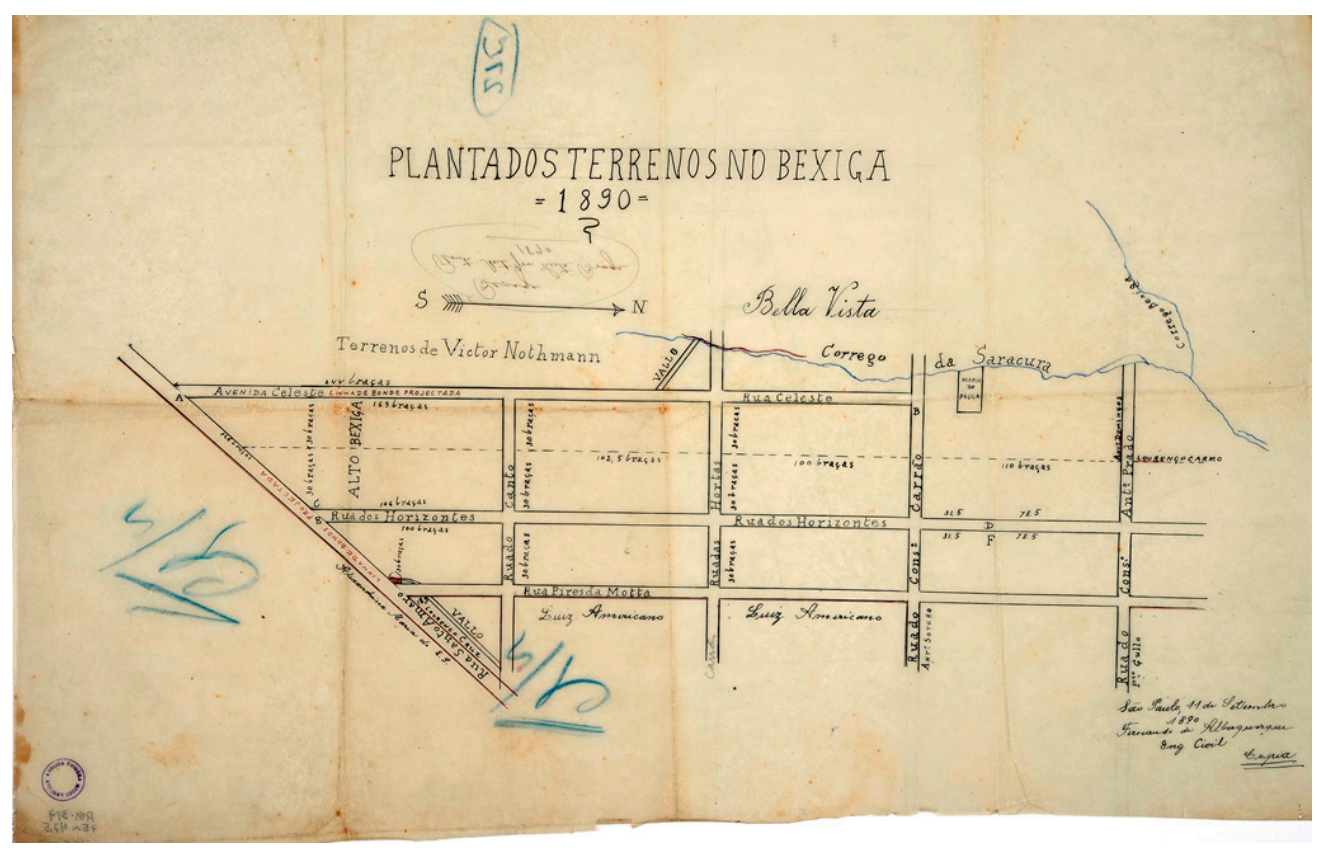

Figura 1 - Planta dos Terrenos no Bexiga. Fernando de Albuquerque, 1890. No croquis delineiam-se as ruas que conformaram a área ocupada pelo bairro. As nomenclaturas mudaram, mas o traçado se mantém praticamente inalterado. Fonte: Arquivo Aguirra/Acervo do Museu Paulista, Universidade de São Paulo. 
O córrego da Saracura, em direção à região oeste, e a rua Santo Amaro, em direção à região leste da cidade, indicam atributos naturais e artefatos preexistentes ao empreendimento. As ruas que compõem o desenho do loteamento, com uma nomenclatura que seria alterada posteriormente, correspondem exatamente às ruas Major Diogo, Conselheiro Ramalho, Treze de Maio, Conselheiro Carrão, Manoel Dutra e São Domingos. Porém, no processo de ocupação humana crescente, o empreendimento espraiou-se em diversas direções, como que se amalgamando a outros espaços. Assim, frente à necessidade de compreender o próprio processo de configuração daquele espaço geográfico, a cartografia disponível sobre a cidade de São Paulo foi um instrumento fundamental, iá que através dela foi possível reconstituir o processo de loteamento e apropriação do bairro do Bexiga e sua inserção no conjunto da cidade em expansão.

Ocorre que em 1910, através da lei n 1.242, de 26 de dezembro, a grande área que envolvia o "loteamento original" do Bexiga passou a ser denominada Bela Vista. Ao determinar a criação "do districto de paz de 'Bella Vista', desmembrado do da Consolação, do município da Capital", 30 a lei enfatiza o distrito e não o bairro. Embora os termos da lei indiquem o espaço do distrito como uma unidade administrativa vinculada ao município, eles não definem a área abrangida pelo bairro. Por outro lado, as plantas da cidade elaboradas naquele período, ao adotarem os dois termos, também não fazem a distinção entre as duas instâncias, gerando dúvidas acerca de sua conformação e abrangência. Estendendo a observação às plantas elaboradas nos anos posteriores, em 1916 e 1924 (Figuras 2 e 3), foi possível concluir que em nenhuma delas o Bexiga foi representado como um bairro independente, situação que só viria a se alterar na Planta da Societá Anonima de Rilevamenti Aerofotogrammetrici (SARA-Brasil), de 1930, na qual nenhum bairro ou distrito recebe qualquer tipo de referência nesse sentido. Por fim, é na planta de 1943 (Figura 4) que o Bexiga volta a constar como um bairro independente, ainda que vinculado ao distrito da Bella Vista.

Perante as dificuldades do olhar contemporâneo em separar o bairro do distrito, se faz necessário restringir o foco espacial do trabalho. Tomando como ponto de partida o Largo do Riachuelo, local que delimitava a fronteira do Bexiga com o Centro, busquei contemplar aquela que foi a área do loteamento original do bairro, sem, contudo, ignorar parte do que se convencionou chamar de Bela Vista. Nesse sentido, a região do Vale da Saracura, cujo início da ocupação, ainda que rarefeita, antecedeu o empreendimento original, forçosamente seria incluída no trabalho. Entretanto, as águas e ribanceiras do córrego, ao interpor barreiras físicas ao deslocamento dos moradores, estabeleceram um segundo limite físico do bairro. Por fim, uma terceira área somou-se às anteriores, por contiguidade, e corresponde 


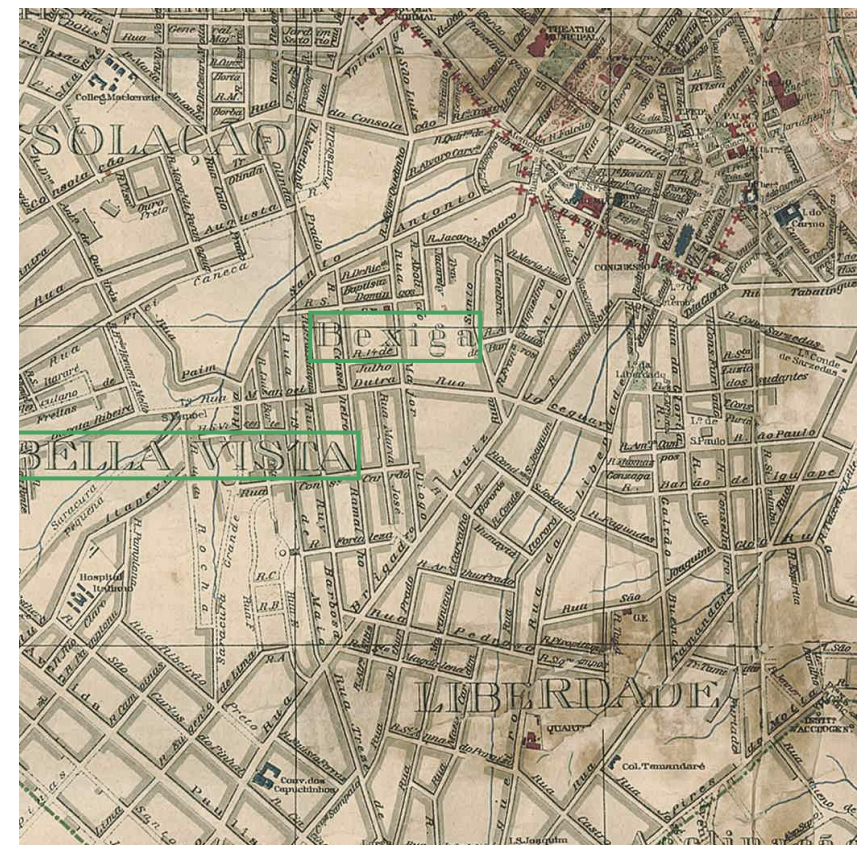

Figura 2 - Planta Geral da Cidade de São Paulo. Divisão Cadastral da $2^{a}$ Secção da Diretoria de Obras e Viação da Prefeitura Municipal (edição provisória), 1916. Fonte: Acervo Histórico Demográfico do Município de São Paulo. Nesta planta a distinção entre distrito e bairro pode ser interpretada pelo destaque dado a cada um: o distrito Bella Vista grafado em letras maiúsculas, e logo acima, o bairro Bexiga grafado em letras minúsculas.

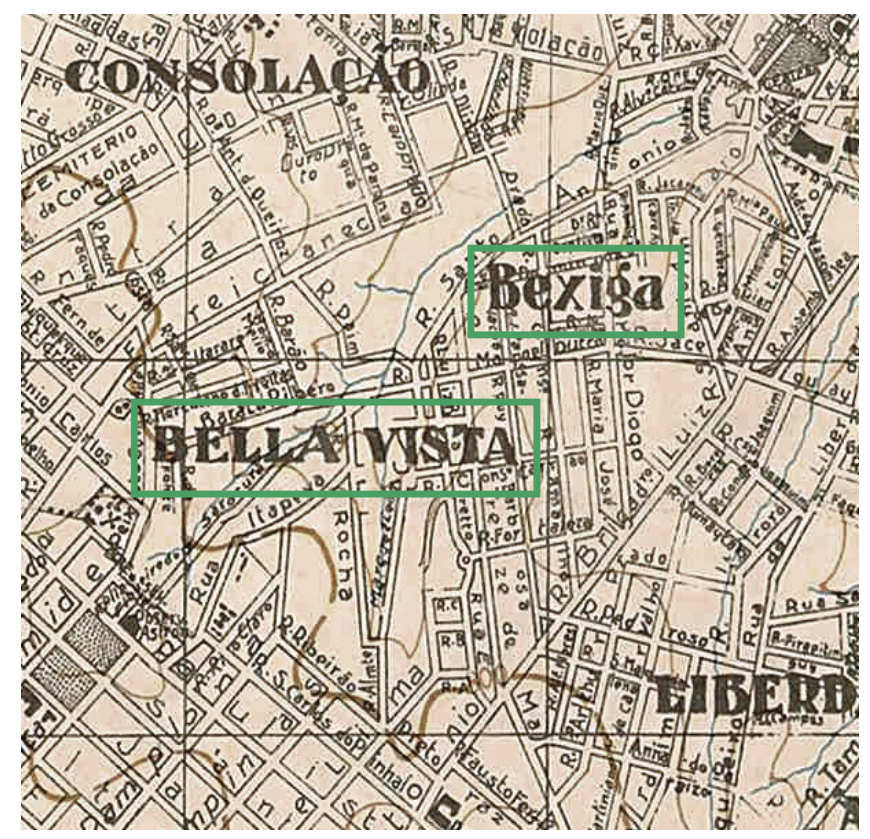

Figura 3 - Planta da Cidade de São Paulo mostrando todos os arrabaldes e terrenos arruados, 1924. Fonte: Acervo Histórico Demográfico do Município de São Paulo. A distinção entre os dois nomes, Bella Vista e Bexiga, se mantém. 


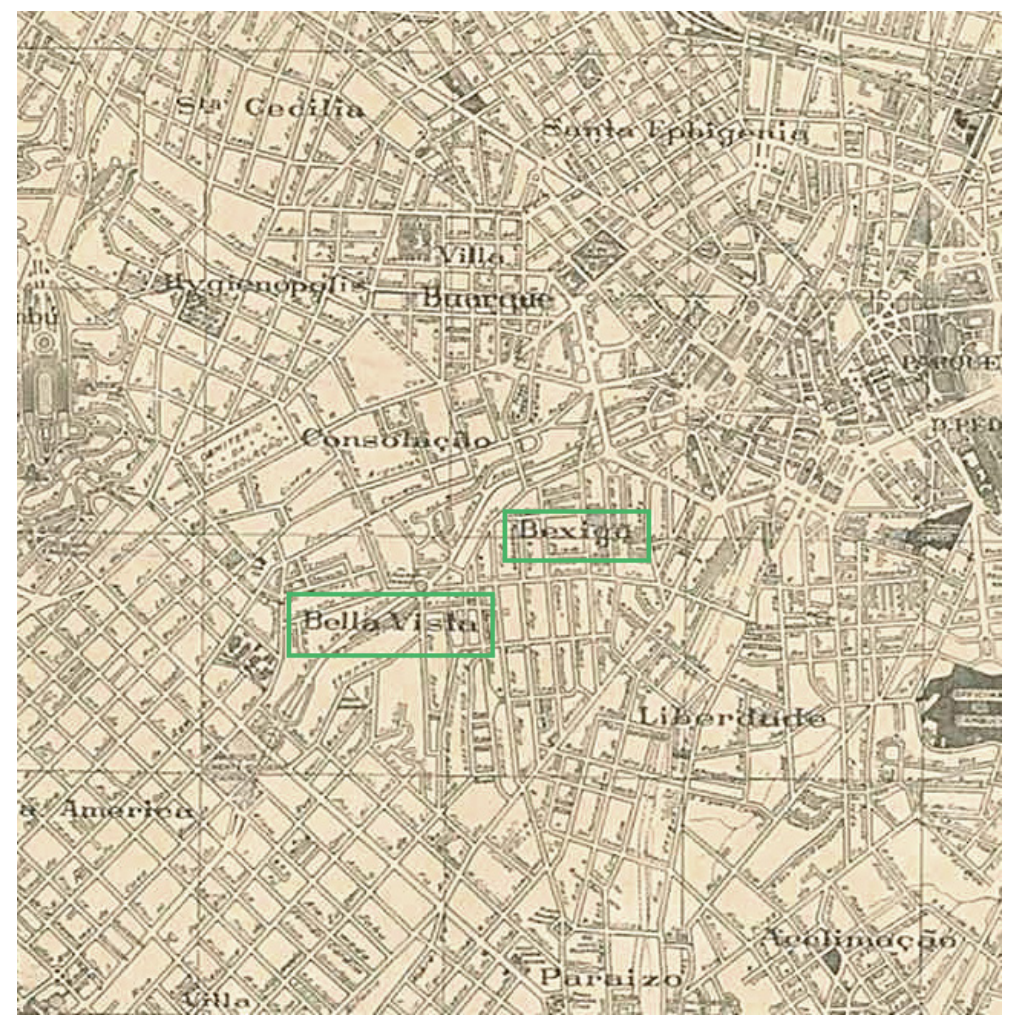

Figura 4 - Planta da Cidade de São Paulo e Municípios Circunvizinhos. The São Paulo Tramway Light and Power, 1943. Fonte: Instituto Geográfico e Cartográfico do Estado de São Paulo. Nesta planta observa-se que a mesma grafia foi adotada para os nomes, ambos em letras minúsculas.

às ruas abertas pela Baronesa de Limeira alinhadas ao loteamento original. Tratavase, pelas dimensões dessa terceira área, de um espaço restrito, sujeito a ser envolvido pelo caráter mais amplo dado pela ocupação do loteamento vizinho - a Liberdade -, que de acordo com as plantas elaboradas entre 1905 e 1924, tinha limites imprecisos entre a rua Tamandaré e a avenida Brigadeiro Luís Antônio. Por sua vez, a avenida, artéria do loteamento da Baronesa de Limeira, pela sua condição articuladora do Centro e da Liberdade estruturou-se numa tríplice função, de local de atividades produtivas, de ocupação humana e via de acesso, representando a verdadeira fronteira, aí entendida no sentido metafórico de lugar de "encontros", e não de barreira física, tal como definida por Burke, ${ }^{31}$ entre os bairros do Bexiga e a Liberdade. É evidente que, a depender do interesse particular de cada observador, os critérios adotados para a delimitação da área de estudo podem ser questionados, mas creio que se prestem ao propósito deste trabalho, envolvendo, portanto, o loteamento original, a zona do Saracura e o loteamento da Baronesa de Limeira. 
Os primeiros sinais de ocupação do espaço datam de 1882, ocasião em que a construção das primeiras casas dá indicações sobre a viabilidade do empreendimento que aos poucos foi se concretizando. Simultaneamente os primeiros negócios foram instalados, e em 1906 a presença de quitandas, armazéns de secos e molhados, açougues, jogos de bola, padarias e oficinas demonstra que o bairro já apresentava certo amadurecimento em termos de suas práticas produtivas, confirmando as expectativas dos primeiros empreendedores.

No processo de sedimentação da nova ordem econômica, diferentes papéis foram representados pelos atores sociais, fossem eles oriundos da oligarquia cafeeira, estrangeiros recém-chegados, ou personagens urbanos anônimos. De um lado, membros de famílias tradicionais, como os Paes de Barros e os Souza Queiroz, que, além da atividade agroexportadora, atuaram em outras frentes, inclusive na especulação imobiliária, e nesse caso não se restringiram a iniciativas de grande porte, mas tendo estendido seus negócios a empreendimentos populares, caso por exemplo do arruamento empreendido pela Baronesa de Limeira, em 1894, em terras que pertenciam à antiga Chácara do Barão de Limeira, entre o Largo do Riachuelo e a avenida Brigadeiro Luís Antônio.

Ao lado dos membros da oligarquia, também atuaram no promissor mercado imobiliário na antiga Chácara do Bexiga imigrantes possuidores de capital necessário para investir em terras, como Victor Nothmann, membros da família Clark e o negociante português Antônio José Leite Braga, proprietário da maior porção de terras na região. Após a morte de Braga, entrou em cena o engenheiro Fernando de Albuquerque, um dos principais agentes responsáveis pelo empreendimento. Em paralelo, se a planimetria do bairro coube a grupos de mais posses, a volumetria resultou de ações de imigrantes e brasileiros integrantes das camadas médias, para os quais a "modernidade" almejada colocava novas opções de inserção social através da exploração de pequenos e médios negócios. Dessa forma os imigrantes destituídos de recursos encontraram na cidade em expansão e transformação tanto a possibilidade de sobrevivência como a oportunidade de conquistar um espaço social. Naquele momento, a atuação praticamente isolada do imigrante no mercado da construção civil, ao lado de certo espírito empreendedor, abriu perspectivas para a formação de um pecúlio através da compra de terrenos e da construção de moradias para locação. De outro lado, entre 1912 e 1914, o bairro já dava sinais da proliferação das habitações coletivas e do processo de "encortiçamento" que viria a ocorrer nas décadas seguintes.

Ao lado das inúmeras construções particularmente destinadas a moradia, envolvendo tipologias variadas - como casas de fundo de lote, vilas e sobrados, 
quando não a transformação e o aproveitamento dos espaços disponíveis em habitações coletivas ou cortiços -, focalizei os inúmeros espaços construídos ou adaptados para o exercício de atividades produtivas. Os requerimentos encaminhados à Diretoria de Obras do município solicitando licença para a construção e/ou reforma de prédios indicam que a sala da frente de muitas casas foi reiteradamente transformada em espaço para negócios, assim como os barracões construídos nos fundos dos terrenos foram ocupados por fabriquetas ou simples oficinas que faziam de tudo um pouco: conserto de peças utilizadas no dia a dia (como máquinas de costura, carroças estacionadas nas cocheiras, ferragem dos animais); fabricação de gradis e portões utilizados nas construções etc. Oficinas também funcionaram no espaço doméstico, não necessariamente no cômodo da frente, mas frequentemente nos porões, comumente utilizados por costureiras, alfaiates e sapateiros. Se de um lado é possível observar a heterogeneidade na paisagem, resultante da ação de mãos tão diversas, de outro se constata a diversidade de atividades produtivas ali instaladas.

O ritmo de ocupação do espaço físico acentuou-se no decorrer dos anos 1920. As áreas livres reduziram-se, e construções mais antigas cederam lugar a novas edificações voltadas à moradia ou ao trabalho; antigas cocheiras foram substituídas por casas destinadas a residências ou por barracões destinados a algum tipo de manufatura. Os embates contínuos entre proprietários e a municipalidade apontam para o aproveitamento exaustivo dos espaços ainda vazios, onde a construção de cômodos poderia dar ensejo à instalação de novos cortiços. Por outro lado, no caso das solicitações de licença para construção e/ ou reforma de imóveis, as inúmeras intimações, multas e embargos, que por vezes envolviam um único processo, colocam em evidência o comportamento reincidente de proprietários e construtores, demonstrando a crescente perda de controle da situação por parte da Diretoria de Obras frente ao acirramento da especulação imobiliária, evidenciando a tendência do que iria ocorrer neste e noutros bairros populares da cidade nas próximas décadas.

\section{COTIDIANO E TRABALHO}

Ao concentrar uma parcela das atividades produtivas excluídas do Centro pela Legislação Sanitária, o Bexiga certamente desempenhou um importante papel na hierarquia produtiva da cidade, diferenciando-se de outros bairros - como o Brás, a Mooca e a Barra Funda -, ao não agregar fábricas e operários, mas 
aproximando-se deles ao desenvolver certos tipos de atividades destinadas ao abastecimento de outras áreas da cidade. Ali se instalaram pessoas de pequenas e médias posses, assim como o comércio mais simples voltado basicamente ao abastecimento alimentar e à prestação de serviços menos especializados, apresentando a coexistência entre moradia e trabalho.

Um dos objetivos deste trabalho é precisar o papel desempenhado pelo bairro do Bexiga e, consequentemente, por seus moradores no mercado informal de trabalho. Ainda que ali tenham se realizado atividades produtivas aparentemente "menores" do ponto de vista da macroeconomia, com pequenos estabelecimentos comerciais e de serviços, acredito que elas tenham sido fundamentais para o funcionamento do todo, na medida em que os negócios ali abertos tinham papel específico no processo de reespacialização das funções urbanas.

No período compreendido entre 1906 e 1914, as solicitações encaminhadas ao poder público por comerciantes do Bexiga indicam a presença de 76 quitandas, ${ }^{32}$ número que naquele momento mostrava-se desproporcional para as necessidades dos moradores do bairro. Levando-se em conta que aquele era um tempo em que não havia como conservar produtos perecíveis, a presença de vários desses estabelecimentos numa mesma rua, muitas vezes distantes poucos metros entre si, impõe o questionamento sobre quem seriam os possíveis consumidores dos produtos ali comercializados.

A busca de resposta a essa pergunta resultou na hipótese central deste trabalho: de que a clientela potencial para os produtos vendidos nas quitandas não estivesse vinculada apenas aos moradores do Bexiga, mas se encontrasse fora dos limites do bairro. Os depoimentos de alguns memorialistas sobre a cidade naquele período fornecem os indícios iniciais que norteiam essa hipótese. É o caso de Jorge Americano, ${ }^{33}$ que em suas memórias de infância dedicou um capítulo inteiro aos vendedores ambulantes que circulavam pelas ruas dos Campos Elíseos. Entre os inúmeros personagens listados por ele, hipoteticamente, alguns bem poderiam ser originários do Bexiga: o leiteiro, a carroça de verduras, a carroça do padeiro, o homem que vendia frangos, o fruteiro, o caixeiro do armazém, o baleiro, o sorveteiro etc.

Bexiga era um território encravado entre os bairros ocupados pelas camadas médias e altas da população - o Morro dos Ingleses, a Liberdade, o Paraíso, a Avenida Paulista e, desde os anos 1920, a Vila América latual Jardim Paulista). Com exceção da Liberdade e do Paraíso, marcados por uma mescla de usos residenciais e comerciais, os demais bairros possuíam um caráter exclusivamente residencial. Parece bastante razoável a ideia de que a localização do Bexiga em relação a esses bairros colocasse os negócios de comércio de alimentos em situação privilegiada.
32. Cf. Série Alvará e Licença (1906-108).

33. Americano (2004, p. 103-112). 
34. Obras Particulares (1906-1923).

\section{AS COCHEIRAS}

Um artefato predominante no bairro também corrobora esta hipótese: as inúmeras cocheiras presentes nas ruas do Bexiga, identificadas na Série Obras Particulares ${ }^{34}$ - utilizadas como uma espécie de estacionamento -, abrigavam carroças e animais, essenciais para o transporte de pessoas e mercadorias. As oitenta cocheiras de presença comprovadamente identificada entre 1906 e 1923 sinalizam que parte dos veículos ali guardados servia à distribuição de alimentos comercializados em quitandas e armazéns do próprio bairro, possivelmente voltadas ao fornecimento dos bairros lindeiros.

O Bexiga envolve uma área de grandes proporções espaciais, e as cocheiras estiveram presentes em praticamente todo o bairro (Figura 5), com exceção das ruas próximas ao Centro, o que deve ser atribuído à proibição desse tipo de atividade em locais "em que a população for densa", como estabelecido pelo Código Sanitário de 1894. Embora o maior número dessas atividades estivesse concentrado nas ruas Treze de Maio e Rui Barbosa, elas se disseminaram por praticamente todas as demais vias do bairro. Com exceção das ruas mais curtas - as transversais São Domingos, Quatorze de Julho, Manoel Dutra, São Vicente, Conselheiro Carrão e Fortaleza - quase todas eram vias que desembocavam na avenida Brigadeiro Luís Antônio, principal eixo de articulação com o Centro e a avenida Paulista.

Das oitenta cocheiras identificadas, foi possível comprovar dezesseis casos que envolviam algum tipo de negócio. Situação, por exemplo, da casa de secos e molhados de Domingos Longo, localizada à rua Major Diogo no 83. Em 17 de maio de 1911 1, Domingos solicitou à Diretoria de Obras licença para a "construção de uma casa com armazém e cocheira" com sete baias nos fundos do terreno. Entre 1913 e 1923, o endereço fornecido por ele consta no Almanak Laemmert como sendo uma casa de secos e molhados. $O$ negócio deve ter prosperado porque alguns anos mais tarde, em 10 de fevereiro de 1919, Domingos solicitou licença para "reforma da cocheira", reduzindo suas dimensões, "de 27 para 16 baias", o que significa que em um momento anterior ela já havia sido aumentada.

Um aspecto a ser levado em consideração refere-se à localização das cocheiras. A cocheira de Longo localizava-se próximo à rua Conselheiro Carrão, e os fundos do terreno davam acesso à rua Humaitá, que em 1930 ainda não tinha sido arruada. Assim, os veículos da cocheira dispunham de duas opções de acesso à avenida Brigadeiro Luís Antônio: pela rua Major Diogo ou (mais fácil ainda) pela Humaitá. Se seguissem a rua Humaitá, logo estariam no bairro da 


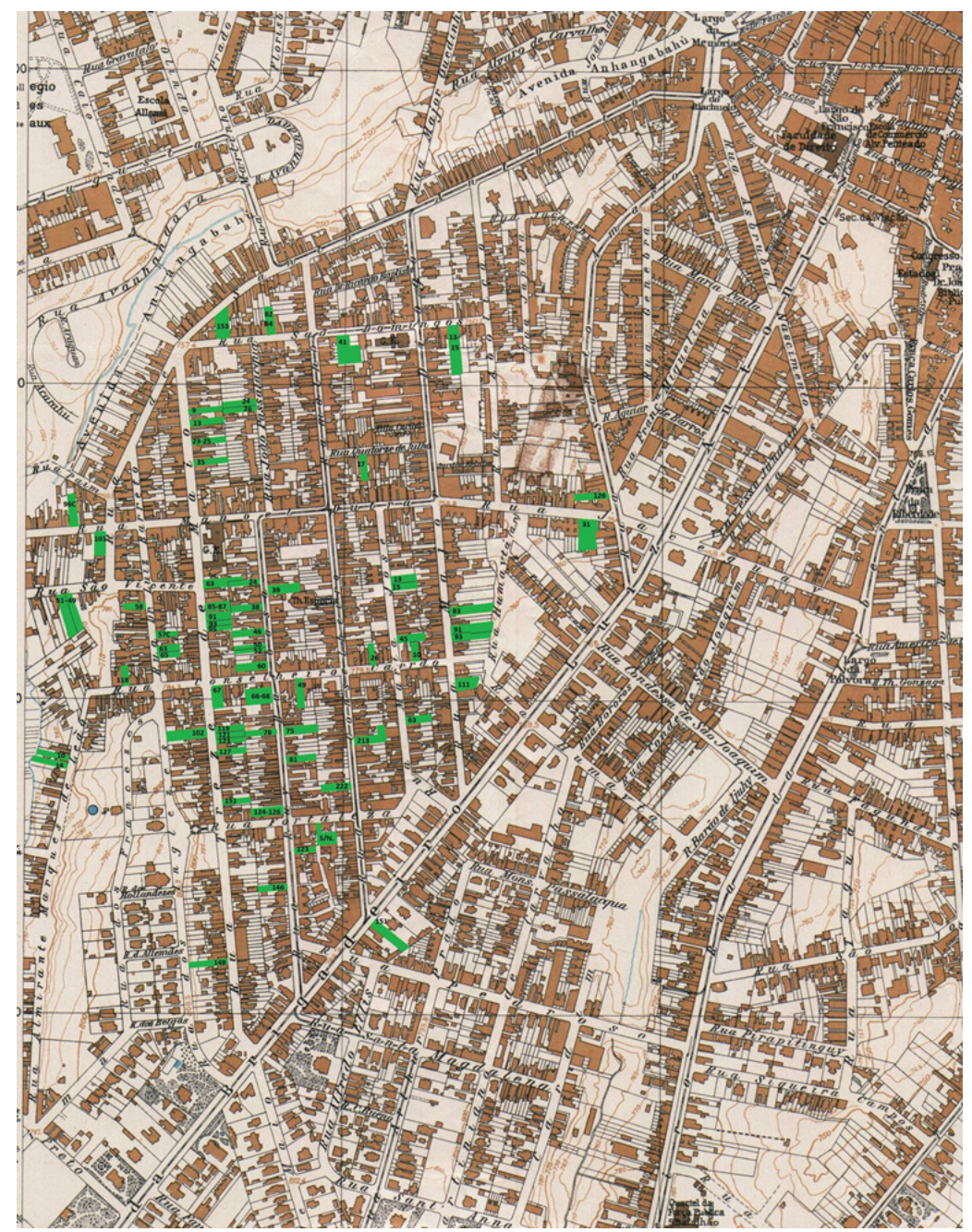

35. Posteriormente, em 5 de maio de 1919, o imóvel seria alvo dos serviços de Emplacamento da Prefeitura, quando sua numeração foi alterada para 157.

Figura 5 - Espacialização conjectural das cocheiras no bairro do Bexiga, entre 1906 e 1923. Planta SARA Brasil, 1930. Fonte: Acervo do Arquivo Histórico Municipal/SMC/DPH.

Liberdade ou no Paraíso; iá, se optassem pela avenida Brigadeiro Luís Antônio, esta, além de abrir caminho para o Centro e à avenida Paulista, permitia acessar os outros imóveis de Longo naquela mesma via.

Embora a avenida Brigadeiro Luís Antônio (muito bem localizada) tenha sido ocupada preferencialmente pelos segmentos mais abastados e por atividades produtivas mais especializadas, ali também havia uma cocheira. Era o caso da Padaria e Confeitaria Nova Suissa, de propriedade de Honesto Cinquini, localizada no no 151.35 Em 1913 Cinquini construiu nos fundos do terreno, ao lado do estabelecimento, um depósito de cereais para sua padaria. Somente em 1915 ficamos sabendo que anexa à padaria havia uma cocheira, ocasião em que 
36. Obras Particulares (1913; 1915; 1919).

37. Obras Particulares (1915). ele solicitou licença para reformá-la, sem mencionar suas dimensões. Alguns anos mais tarde, em 1919, Cinquini encaminhou à Diretoria de Obras um pedido de licença para fazer uma "reforma e aumento de armazém". ${ }^{36}$ Os três casos se relacionam diretamente ao negócio que, de acordo com o Almanak Laemmert, funcionou naquele endereço entre 1910 e 1923.

Em 13 de outubro de 1909 o construtor David Dias Ferreira encaminhou requerimento à Diretoria de Obras, visando "a construção de quarto para forragens, na sequência de uma cocheira existente", na rua Jaceguai n 31 , mesmo local indicado pelo Almanak Laemmert como sede da Padaria Java, de propriedade da firma Gonçalves \& Cunha, nos anos 1914 e 1915. Conforme notícia divulgada no jornal $\bigcirc$ Estado de São Paulo, em 28 de junho de 1918, acerca do desaparecimento de duas mulas de uma cocheira, verifica-se que a padaria havia sido transferida para a rua Santo Amaro n ${ }^{\circ} 130 \mathrm{~A}$, porém, a cocheira permanecia na rua Jaceguai.

Carlos Biagini fazia parte do grupo de proprietários de pequenas cocheiras. Ele possuía, pelo menos desde 1913, um armazém de secos e molhados sito à rua Santo Antônio n 149. Em 1915, Biagini solicitou à Diretoria de Obras licença para a "reforma da cocheira existente" na rua Santo Antônio no 153. ${ }^{37}$ De acordo com o projeto encaminhado, o acesso ao terreno e à cocheira (com duas baias) se dava através da rua São Domingos, onde também havia um prédio para "oficina". A cocheira localizava-se numa área muito próxima à rua Martinho Prado, no lado oposto da rua Santo Antônio, em cuja esquina Biagini possuía o sobrado $n^{\circ}$ 156, este também com espaço comercial instalado no piso térreo. Em 1914, esse espaço era ocupado por um bar, propriedade de Alves \& Azevedo, mas a partir de 1921 a casa comercial de Biagini passou a funcionar no local. $\bigcirc$ que importa nessas informações é justamente a localização das propriedades de Carlos Biagini, nas proximidades da rua Martinho Prado, via de ligação entre o Bexiga e a Consolação, o que remete à possibilidade de um intercâmbio comercial entre esses bairros. Quem sabe, os produtos disponíveis no armazém do comerciante podiam ser entregues nos domicílios dos clientes através das carroças estacionadas na cocheira da rua Santo Antônio?

Interessante é o caso da tradicional Padaria São Domingos, na rua homônima. Em 19 de junho de 1913, Domingos Albaneze encaminhou uma solicitação para "construção de um sobrado com armazém" no n 80 daquela rua. Em 21 de janeiro seguinte, Albaneze pediu licença para a "construção de uma cocheira", agora no $n^{\circ} 82$, sendo que no final do mesmo ano outro requerimento dizia que o projeto apresentado pelo peticionário, "residente com padaria neste 
endereço", havia sido "transferido para os fundos do terreno". Ocorre que a nova solicitação se referia ao no 84 da rua São Domingos. Já em 19 de setembro de 1918, Albaneze reformava a cocheira, onde construiria uma baia de isolamento, porém agora no no 82. Domingos Albaneze só iria divulgar seu negócio em 1921, quando $\circ$ Almanak Laemmert registra a presença de uma casa de secos e molhados no $n^{\circ} 80$ da rua São Domingos, e de um açougue no n 82 , ambos em nome de um certo Domingos Alboney, certamente a mesma pessoa. Tudo indica que 0 começo não foi muito fácil e que o comerciante testou diferentes possibilidades antes de consolidar o nome da casa. Em relação à localização, naquele momento a padaria de Albaneze se encontrava nas proximidades da rua Santo Antônio, 38 portanto, com acesso relativamente fácil ao bairro da Consolação, via rua Major Quedinho. A localização também era estratégica para acesso à rua Augusta, via rua Martinho Prado, e ainda para o grande distrito da Bela Vista, através da rua Paim. Para o Centro, o caminho era a rua Santo Antônio.

Quando não relacionadas ao exercício de alguma atividade produtiva específica, as cocheiras podiam se constituir, elas mesmas, num negócio de transporte para terceiros. Um exemplo disso é aquele de Domingos Bruno, que em 1915 era proprietário de uma cocheira com seis baias na rua Major Diogo, constando no lançamento do Imposto de Comércio e Indústria de $1933^{39}$ como proprietário de uma empresa de transportes. Possivelmente a antiga cocheira de Bruno também se destinava ao abrigo de veículos e animais para transporte de objetos, móveis, mercadorias etc., servindo a quem fosse mudar de endereço ou aos comerciantes locais necessitados de veículos para entregar seus produtos. Outro caso se refere a Luís Monticelli, que possuía uma cocheira à rua João Passalacqua $n^{\circ} 26$ desde 1912, ano em que pediu autorização para a sua construção sem definir o número de baias. Monticelli voltou a procurar a Diretoria de Obras para fazer alterações no imóvel em 1915 e 1919, ora indicando três, ora quatro baias. Em 1933 ele aparece como proprietário de uma "garage de aluguel", do que se infere que o espaço não servia mais ao abrigo de animais e carroças, mas sim de automóveis. Não foi possível saber em que momento Monticelli optou por essa mudança, mas a identificação de negócios sujeitos à contribuição do Imposto sobre Comércio e Indústria naquele ano deixa claro que naquele momento a presença do automóvel movido à motor de combustão era uma realidade inquestionável.

Se no período investigado houve um aumento efetivo de processos envolvendo as cocheiras do bairro, a partir de 1920 ocorreu um decréscimo radical. A Série Obras Particulares cobre apenas o período até 1923, inviabilizando constatações posteriores. No entanto, é possível inferir que a partir
38. Entre 1968 e 1971 a rua São Domingos, além de outras vias do bairro da Bela Vista, foi "cortada" pela construção do Viaduto Júlio Mesquita, parte da Ligação Leste-Oeste, o que impede a travessia a pé em direção às ruas Rui Barbosa, Treze de Maio e Santo Antônio.

39. Órgão Oficial dos Poderes do Estado de São Paulo (1933, p. 31). 
dos anos 1930 essas tipologias tenderam a desaparecer. Embora alguns testemunhos iconográficos indiquem a presença de carroças nas ruas da cidade, pelo menos até os anos 1940 (Figura 6), cremos que a partir dos anos 1920 o crescente processo de metropolização da cidade implicou a "expulsão" desse veículo para "novos" arrabaldes. Por outro lado, a cobrança do Imposto de Comércio e Indústria de 1933 indica que na década de 1930 já se iniciava uma gradual substituição dos veículos de tração animal pelos motorizados no transporte de cargas.

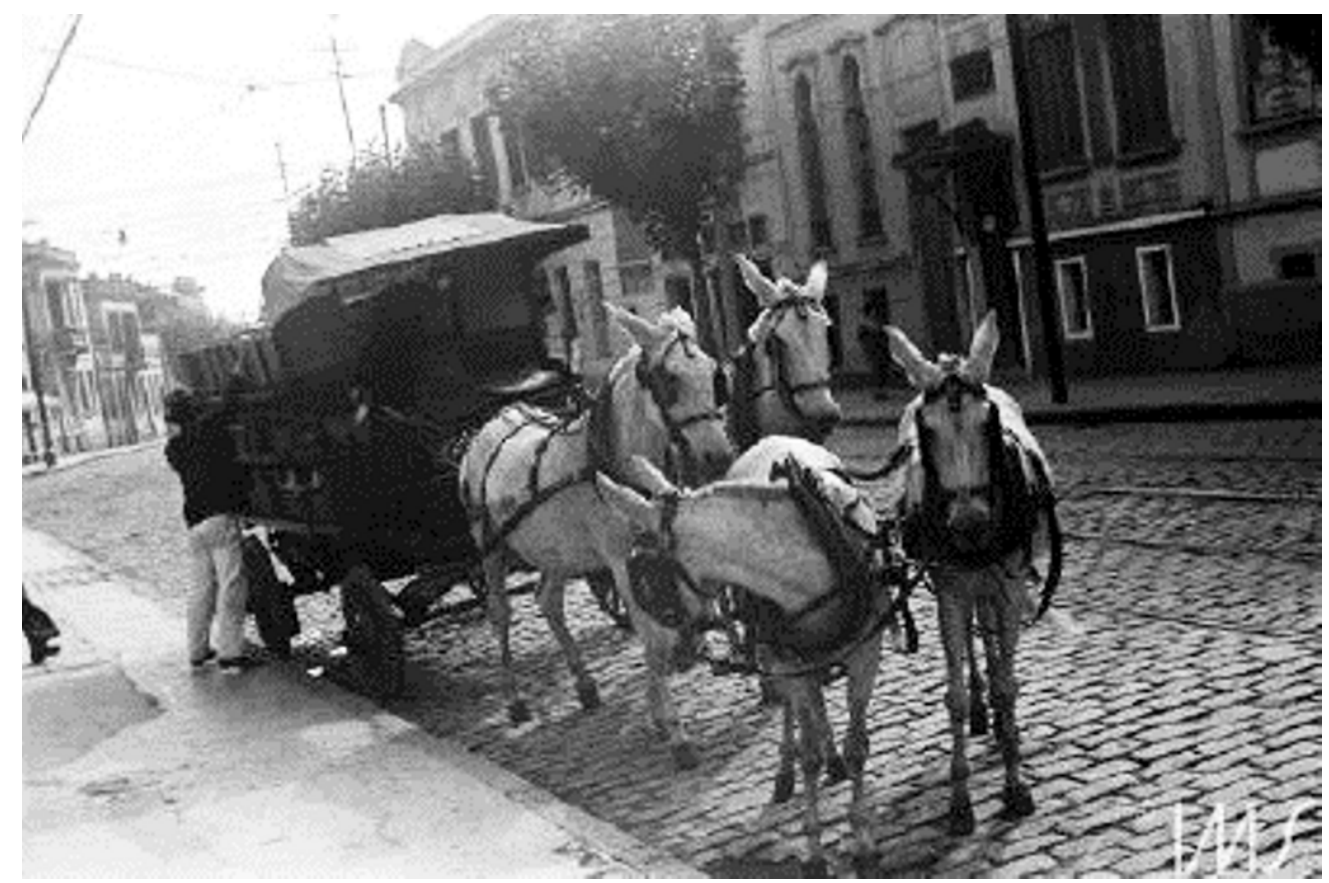

Figura 6 - Entregador de bebidas. Fotografia: Hildegard Rosenthal, c. 1940. Fonte: Acervo do Instituto Moreira Salles.

A análise dos casos exemplares relatados acima obedeceu a um esforço de pensar o comércio varejista do Bexiga a partir das possibilidades de circulação dadas pela localização das cocheiras do bairro em relação às vias de acesso a outras regiões da cidade, em resposta a demandas dos bairros adjacentes. Porém, mais do que fornecer respostas conclusivas, a intenção dessa abordagem é explorar e levantar questões referentes à hipótese central deste trabalho. E os estudos de caso de alguns atores sociais que desempenharam pequenos papéis na cidade em processo de expansão mostram que, dentro de sua aparente inexpressividade, esses atores foram fundamentais para o funcionamento do conjunto. 
De acordo com as informações contidas no Almanak Laemmert, nas 41. Moreno (1996, p. 153, grifo nosso). primeiras décadas do século XX as atividades vinculadas ao setor de alimentação, particularmente aquelas voltadas ao comércio de gêneros de primeira necessidade, predominaram no Bexiga: os "armazéns de secos e molhados" indicando o comércio varejista de gêneros "sólidos e líquidos" e as "quitandas" indicando o comércio de verduras, legumes e frutas. No entanto, frequentemente é possível encontrar nessas publicações certa "mistura" dos produtos comercializados. Assim como há casos de estabelecimentos que aparentemente se dedicavam exclusivamente ao comércio de produtos específicos, tais como "embutidos", "molhados finos", "mantimentos", "laticínios", "vinhos" etc., os armazéns de secos e molhados também podiam vender esses mesmos produtos. De outro lado, as quitandas podiam vender "cereais, batatas e cebolas" e "frutas", os quais eventualmente também podiam ser encontrados nas casas de secos e molhados.

A indefinição sobre o tipo de mercadoria comercializada nesses estabelecimentos se estende às padarias, conforme o inventário post mortem de João Ferraz de Campos citado por Maria Luiza Ferreira de Oliveira, documento que relaciona os itens vendidos pelo negociante Domingos Albange, proprietário de uma padaria na rua São Domingos: "pão, caninha, farinha, bacalhau, milho e sardinha". ${ }^{40}$ Além de pão e farinha, produtos característicos de uma padaria, a caninha, o milho, - bacalhau e a sardinha também eram vendidos nas casas de secos e molhados. Armandinho do Bixiga confirmou essa possibilidade em suas memórias:

As padarias eram completamente diferentes de hoje. A padaria vendia arroz, feijão. A Basilicata, fundada em 1914, ainda mantém isso um pouco, as outras não. Vendiam arroz, feijão, milho, alho, tudo, era uma "venda". Só que faziam o pão também. O forte era o empório, mas faziam pão também. ${ }^{41}$

Muitos dos inúmeros espaços construídos ou adaptados para o exercício de atividades produtivas no Bexiga envolveram alguma forma de comércio de gêneros alimentícios. A instalação de fornos nos fundos das casas indicava a presença de padarias, que poderiam estar associadas a uma quitanda ou a um armazém de secos e molhados, assim como os barracões construídos nos fundos dos terrenos podiam ser ocupados por fabriquetas de macarrão, frequentemente ligadas a uma padaria instalada na sala da frente do imóvel. Da mesma forma como ocorreu com a Padaria Basilicata, citada por Armandinho do Bixiga, vale relembrar o caso da Padaria São Domingos, negócio que em certo momento chegou a envolver a comercialização de cereais diversos, pães e carnes. 


\begin{tabular}{|c|c|c|c|}
\hline ÁREA & ESTABELECIMENTOS & SUBTOTAL & TOTAL \\
\hline \multirow[t]{5}{*}{ "ÁREA NOBRE" } & ARMAZÉNS/ SECOS E MOLHADOS & 225 & \multirow{5}{*}{331} \\
\hline & FRUTAS & 14 & \\
\hline & QUITANDAS & 12 & \\
\hline & PADARIAS & 16 & \\
\hline & AÇOUGUES & 64 & \\
\hline \multirow[t]{5}{*}{ LOTEAMENTO ORIGINAL } & ARMAZÉNS/ SECOS E MOLHADOS & 339 & \multirow{5}{*}{493} \\
\hline & FRUTAS & 37 & \\
\hline & QUITANDAS & 14 & \\
\hline & PADARIAS & 22 & \\
\hline & AÇOUGUES & 81 & \\
\hline \multirow[t]{5}{*}{ SARACURA } & ARMAZÉNS/ SECOS E MOLHADOS & 16 & \multirow{5}{*}{20} \\
\hline & FRUTAS & 1 & \\
\hline & QUITANDAS & - & \\
\hline & PADARIAS & 3 & \\
\hline & AÇOUGUES & - & \\
\hline \multicolumn{3}{|l|}{ TOTAL } & 844 \\
\hline
\end{tabular}

Tabela 1 - Ocorrência do comércio de gêneros alimentícios nas três áreas do Bexiga, entre 1906 e 1931 . Fonte: Arquivo Histórico Municipal de São Paulo.

Outro caso que merece ser mencionado é o de José Tosto, que desde 1909 explorava o ramo de alimentação. Naquele ano, ele abriu dois açougues, um na rua Asdrúbal do Nascimento, onde permaneceu até 1916, e outro na rua Major Diogo. Em 1910, ele acrescentou ao açougue da Major Diogo um comércio de secos e molhados. As coisas pareciam estar dando certo para Tosto e, em 1913, talvez contando que valeria a pena se arriscar em um endereço mais privilegiado (e certamente mais caro), ele abriu outra casa na avenida Brigadeiro Luís Antônio, onde continuou a explorar o comércio de carnes e secos e molhados. Ocorre que em 1917 o encontramos com apenas um estabelecimento, aquele da rua Major Diogo n 49 (antigo 43), ocasião em que diversificou seu comércio entre "secos e molhados, ferragens e quinquilharias".

São esses alguns dos casos da diversidade e sobreposição de funções que dificultam a delimitação de fronteiras rígidas entre estabelecimentos e os tipos de produtos ali comercializados.

Por fim, um aspecto importante a se levar em conta, tanto no caso dos armazéns, quitandas e casas de frutas quanto no das padarias e açougues, é que os registros nos anuários não correspondem necessariamente à totalidade dos 
estabelecimentos existentes no bairro naquele período. É bom lembrar que nem todos os comerciantes divulgavam seus serviços nos almanaques, sempre havendo aqueles que, por falta de recursos, por desinteresse ou até mesmo para fugir da cobrança de impostos, se abstinham de anunciar suas atividades.

\section{O SETOR DE SERVIÇOS}

O acúmulo de gente de todas as camadas sociais no bairro e nos arredores demandou prestadores de serviços que atendessem as necessidades múltiplas da população, dos ofícios mais especializados aos mais elementares. Apesar da variedade de serviços identificados nos almanaques, aqueles que pela presença mais constante (e numerosa) foram realmente significativos para os moradores do bairro concentraram-se nos negócios "menores", atendendo as necessidades mais banais, caso sobretudo das barbearias, farmácias e sapatarias. Infelizmente, embora sejam práticas fundamentais para o funcionamento da vida urbana, talvez até pelo seu caráter aparentemente "menor", são raros os textos acadêmicos e de memorialistas a fazer referências a esses ofícios.

Até o século XIX, a profissão de barbeiro esteve associada à prática médica da sangria, método terapêutico utilizado no tratamento de várias doenças. Conforme Betânia Figueiredo, "a distinção entre o barbeiro e o cirurgião processou-se ao longo do século XIX, marcada pela formação acadêmica do cirurgião, em contraponto com a informalidade das atividades do barbeiro". 42 É provável que no início do século XX os serviços dos barbeiros já se limitassem a fazer a barba e cortar o cabelo. No exemplar do Almanak Laemmert de 1906 constam dezessete profissionais dedicados a tais práticas, sendo que apenas um deles se localizava no Bexiga. Já na publicação de 1908, a categoria possuía cerca de 380 profissionais distribuídos por toda a cidade de São Paulo, catorze deles radicados no bairro do Bexiga. No decorrer de aproximadamente 25 anos, sua presença foi uma constante, tendo chegado a 85 o número total de barbeiros identificados, alguns deles atuantes durante muitos anos. Esse foi o caso, por exemplo, de Antônio Musto, estabelecido na rua da Abolição desde 1909 até 1931; de Carmine Grecco, com salão à avenida Brigadeiro Luís Antônio entre 1909 e 1931; de Nicolau Oddone, na rua Conselheiro Ramalho de 1909 a 1931 ; e de Victor Mussumecci, cujo salão entre 1909 e 1927 se localizava na rua Santo Antônio, e em 1931 se mudou para a rua Treze de Maio. 
43. De acordo com Salles e Santos (2001), por iniciativa de grupos de imigrantes bem-sucedidos e de alguns médicos italianos, foram organizadas na cidade de São Paulo as sociedades italianas de socorro mútuo, caso da Sociedade Italiana de Beneficência, em 1878, assim como foi criado o Hospital Umberto I, em 1904, e a Casa de Saúde Francisco Matarazzo, em 1915, anexa àquele hospital.

44. Malatian (1996).

45. Malatian (1996, p. 193206, grifo nosso).
Redefinidas as funções de barbeiros e farmacêuticos, na área da saúde, durante o período investigado, verifiquei um número razoável de farmácias distribuídas pelo bairro do Bexiga. No loteamento original elas se destacam particularmente a partir de 1918, quando são seis; em 1922 e 1923 passam a ser dez, reduzidas em 1927 a oito e voltando a se disseminar em 1931, com nove farmácias. Por se tratar de uma região densamente povoada, cuja população, em sua maioria, pertencia às camadas médias e baixas, é de supor que o serviço farmacêutico tenha sido, se não fundamental, de grande importância para os moradores do bairro. Embora houvesse um grande hospital voltado ao atendimento desses segmentos nas proximidades do Bexiga, caso do Hospital Humberto I e da Casa de Saúde Francisco Matarazzo, anexa ao hospital ${ }^{43}$ localizados na Alameda Rio Claro, as farmácias certamente eram a referência para primeiros socorros.

Como ocorreu com o comércio de alimentos, noto a conjugação de diferentes modalidades de negócio nos estabelecimentos voltados ao conserto de calçados. Nas listagens das atividades produtivas elaboradas a partir dos levantamentos dos anuários, entre 1906 e 1931, frequentemente o mesmo agente divulga seu negócio ora como sapateiro, ora como sapataria ou ainda como casa de calçados. Como exemplo, em 1918 temos Lanfranchi \& Cia. e Roque Mariani \& Filho, respectivamente localizados na avenida Brigadeiro Luís Antônio, nos números $22 \mathrm{~B}$ e 25 . Ambos anunciavam seus negócios como casas de calçados, dando a entender que ali se comercializava o produto. Já entre 1922 e 1923, seus anúncios designam sapatarias, levando-nos a crer que se tratava de uma prestação de serviços. Em 1913, o mesmo Roque Mariani anuncia seu negócio como sapateiro, que no linguajar atual significa o profissional que conserta calçados. É bem provável que esses profissionais realmente realizassem todas as operações apontadas nos almanaques - fabricação, consertos e comércio.

Um trabalho interessante que abordou a construção de uma identidade coletiva por sapateiros e curtumeiros foi desenvolvido por Teresa Maria Malatian. ${ }^{44}$ Tendo colhido depoimentos dos operários da indústria de calçados na cidade de Franca, a autora traz informações que ajudam a resgatar o significado do trabalho desenvolvido por esses trabalhadores:

As lembranças registradas sobre a fabricação de calçados recuam à década de 1920 e referem-se à forma artesanal de produção [...] A produção era feita em pequenas unidades familiares, situadas nas residências dos proprietários dos negócios, com emprego reduzido de assalariados.[...] $\bigcirc$ processo produtivo baseava-se na habilidade do artesão em trabalhar o couro utilizando instrumentos como faca, martelo, torquês, alicate e lamparina a álcool. ${ }^{45}$ 
A referência no texto à "produção em pequenas unidades familiares, situadas nas residências dos proprietários dos negócios" remete a uma realidade comum ao Bexiga, independentemente do tipo de negócio explorado - a coexistência, num mesmo espaço, de trabalho e moradia. Tratando-se de um bairro onde, com raríssimas exceções, inexistiam estabelecimentos fabris é compreensível que o mesmo profissional que dominasse determinado ofício desenvolvesse, a par dessa atividade específica, outras correlatas. Caso houvesse uma clientela disponível, o produto final de seu trabalho poderia ser comercializado, do contrário, o conserto de calçados sempre garantiria um ganho básico para a sobrevivência familiar. A implantação de uma manufatura requeria investimentos razoavelmente altos em insumos - maquinaria, matéria-prima e, eventualmente, mão de obra auxiliar. Dessa maneira, é compreensível que se buscasse explorar todas as possibilidades oferecidas pelo domínio de determinada atividade, de preferência na mesma edificação da moradia, sem que houvesse necessidade de gastar mais com o aluguel de um outro espaço.

\section{O TRABALHO INFORMAL 46}

Do rol de profissionais que desempenharam atividades produtivas de maneira informal na cidade, as lavadeiras parecem ter sido aquelas que mais visibilidade tiveram. São bem conhecidas as imagens deixadas por fotógrafos como Marc Ferrez, Guilherme Gaensly e Militão, que documentaram a cidade em fins do século XIX e nas primeiras décadas do XX. Ao lado das imagens um tanto idílicas desses fotógrafos, as observações feitas por memorialistas, como Geraldo Sesso Júnior, não deixam dúvidas quanto à ideia que se fazia dessas profissionais, associando-as muitas vezes a comportamentos desviantes (desordem, alcoolismo, roubo e prostituição) e a práticas que contrariavam a ideologia higienista da época:

Acontecia que muito antes de se acomodarem, cada qual em seus lugares, já se iniciava a discussão que era acompanhada de impropérios e palavrões e terminava em brigas - tudo isso para a disputa de melhores lugares. Raro o dia em que a polícia não era chamada a intervir, havendo, às vezes, até necessidade de as autoridades realizarem alguma prisão, principalmente quando se tratava de lavadeiras mais exaltadas, que brigavam como homem. ${ }^{47}$

Fatos citados em pequenas notas do jornal $\bigcirc$ Estado de São Paulo ${ }^{48}$, em que o alcoolismo, a histeria e as intrigas são vistos como causas geradoras de ocorrências médico-policiais, aconteceram em momentos diferentes e locais distantes das várzeas dos rios, entretanto só confirmam a permanência do estereótipo.
46. O conceito "trabalho informal", embora possa não se aplicar à realidade urbana da São Paulo das primeiras décadas do século $\mathrm{XX}$, foi aqui adotado tendo em vista a necessidade de adequar/ acomodar as atividades não contempladas pelo Almanak Laemmert. Tratase das atividades supostamente "menores", que não mereceriam figurar nas páginas daquele anuário. Em contrapartida, o conceito de "comércio especializado" refere-se a atividades que, embora características das ruas do Triângulo, também foram identificadas em algumas ruas do bairro aqui analisado.

47. Sesso Júnior (1983), apud Santos (1998, p. 99100).

48. O Estado de São Paulo (1902, 1913, 1929). 
49. Grünspun (1979, p. 32, grifo nosso).

50. Grünspun (1979, p. 33).

51. Campos (2002, p. 7479).

52. Reis Filho (2004a), p. 44).
Haim Grünspun demonstra que o trabalho das lavadeiras se mantém nos anos 1930, não por acaso, em um bairro predominantemente ocupado pelas camadas médias e baixas da população:

Esta era uma das profissões mais comuns no Bexiga: lavar roupa para fora. Quando as freguezas eram do próprio Bexiga ganhava-se uma miséria porque todos sabiam do preço. Mas quando as freguezas eram de fora do bairro, como Morro dos Ingleses ou Paraíso, dava para ganhar bem. ${ }^{49}$

O memorialista esclarece que o trabalho dessas profissionais também era utilizado pelos moradores mais ricos de bairros vizinhos, caso do Morro dos Ingleses e Paraíso. Em um tom menos ácido do que as notas jornalísticas de $O$ Estado de São Paulo, Grünspun não se furta a falar sobre o convívio entre as lavadeiras do bairro:

Quando num mesmo cortiço havia mais de uma lavadeira para fora, os dias de lavagem eram diferentes [...] Tudo isto na santa paz do senhor? Nada disso. Tudo com briga e muita discussão e xingamento como rotina. ${ }^{50}$

A fotografia de autor desconhecido (Figura 7), elaborada provavelmente em função da abertura da Avenida Anhangabaú (atual Nove de Julho), que ligaria - Centro ao sul da cidade, confirma a presença das lavadeiras no Bexiga. No centro da imagem, à direita do córrego da Saracura, as roupas nos varais e nos quaradouros permitem visualizar o trabalho dessas profissionais. A mesma realidade se repete na foto de Geraldo Horácio de Paula Souza (Figura 8), realizada quando foi diretor do Serviço Sanitário do Estado de São Paulo. ${ }^{51}$

Aparentemente menos estigmatizadas que as lavadeiras, as criadas, copeiras e cozinheiras também fazem parte desse universo do trabalho doméstico informal. Não é demais lembrar que desde o período colonial o trabalho braçal, doméstico ou não, era visto pelas classes dominantes como uma ocupação "menor" que cabia a escravos ou assalariados, por sua vez também tão invisíveis que as fontes documentais raramente se reportam a sua presença. Com a abolição da escravidão, a dependência do trabalho doméstico transferiu-se para os trabalhadores assalariados, preferencialmente estrangeiros. ${ }^{52}$

Embora as parteiras estejam entre os profissionais da saúde que divulgaram seus serviços no Almanak Laemmert, há boas razões para incluílas também entre 


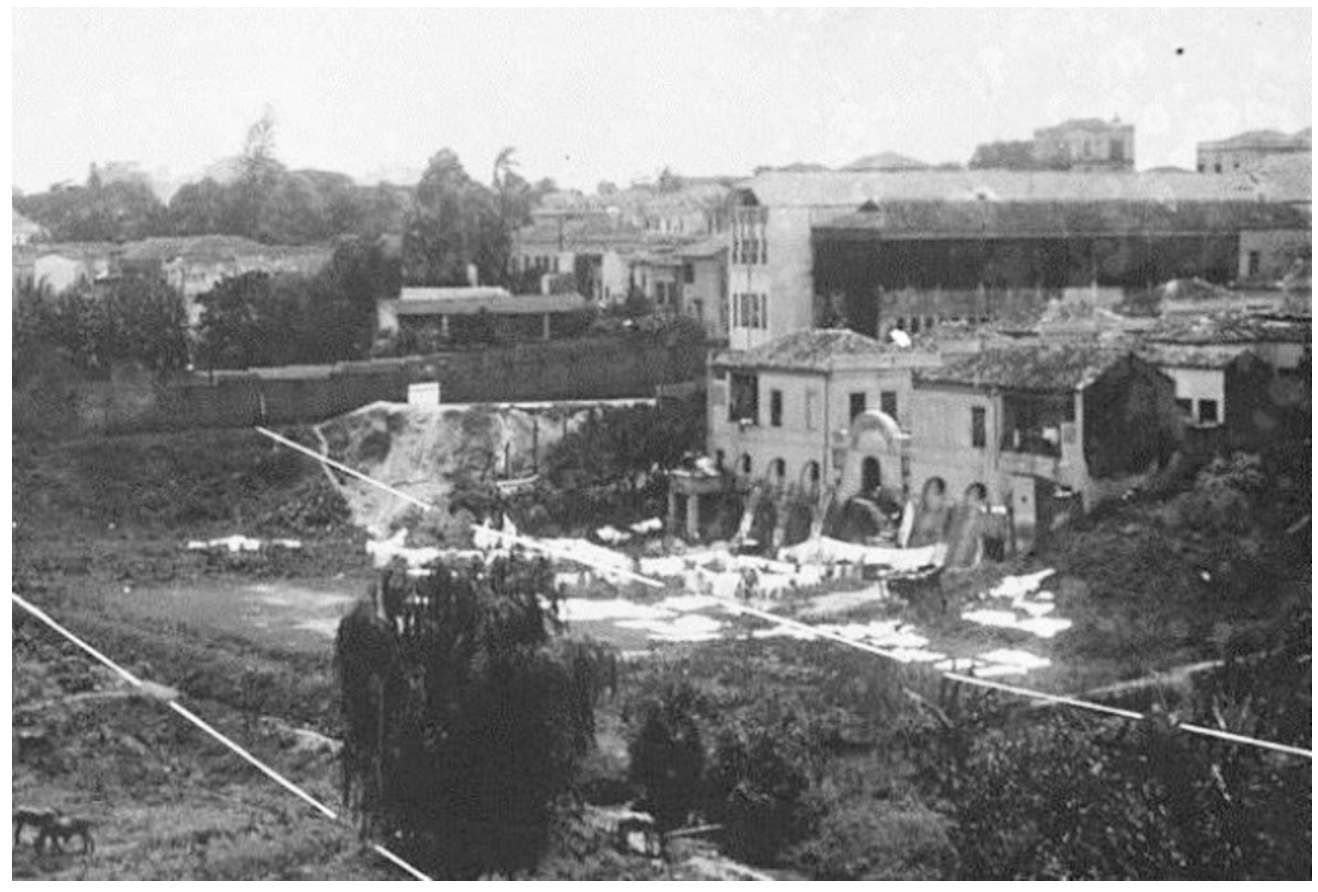

Figura 7 - Recorte de uma fotografia do Vale da Saracura. Autoria desconhecida, c. 1926. Fonte: Acervo do Museu da Cidade de São Paulo.

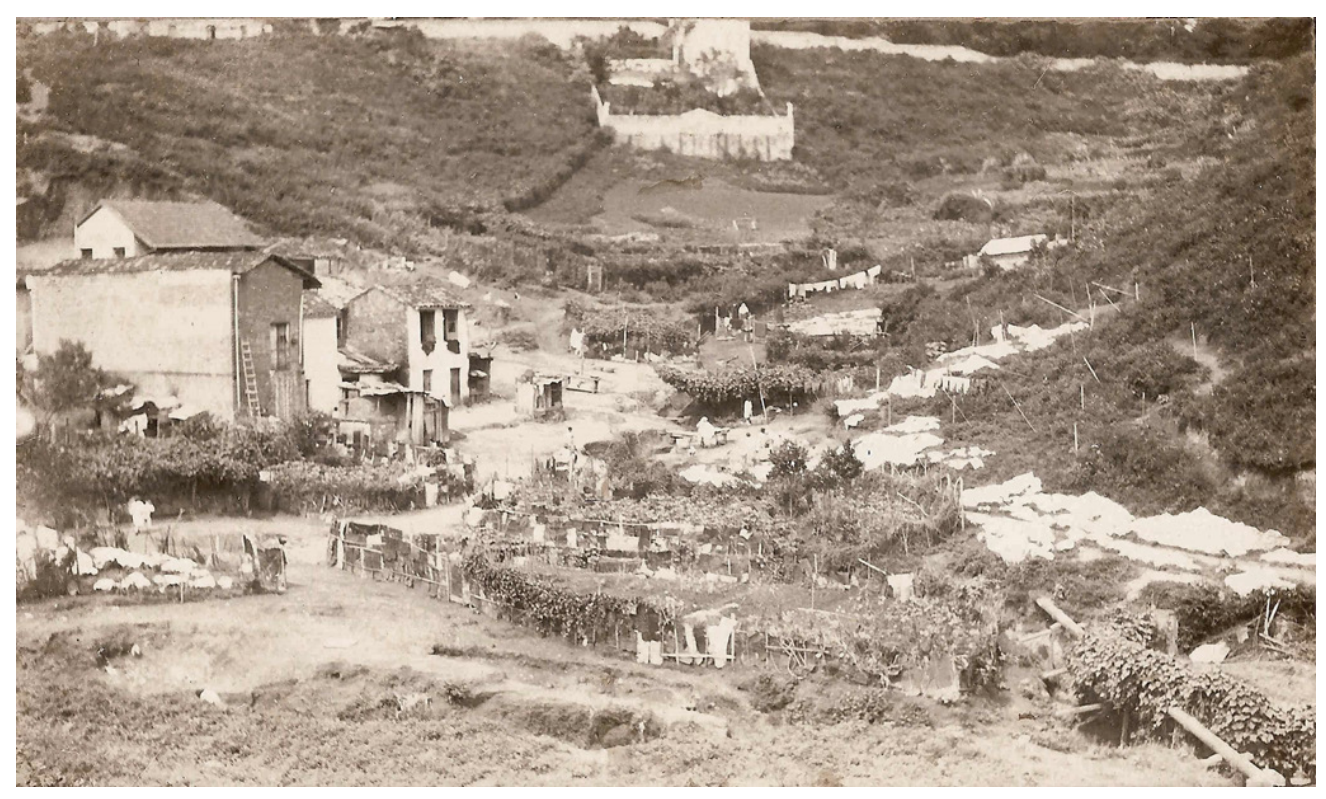

Figura 8 - Vale do Saracura Grande. Fotografia: Geraldo Horácio de Paula Souza, c. 1920. Fonte: Acervo do Centro de Memória da Saúde Pública, Faculdade de Saúde Pública da Universidade de São Paulo. Nesta imagem, as roupas nos varais e nos quaradores demonstram a atividade das lavadeiras. 
53. De acordo com Telarolli Júnior (1993, p. 88), entre 1901 e 1909 o percentual de nascimentos em domicílio na capital paulista variou entre 97,4 e $96,4 \%$.

54. Penteado (2003, p. 215219).

55. Grünspun (1979, p. 109110). os chamados trabalhadores invisíveis. A profissão de parteira foi, desde tempos remotos, praticada por mulheres leigas que faziam o atendimento, domiciliar ou em suas próprias residências, a parturientes. ${ }^{53}$ Do ponto de vista da população, elas eram figuras fundamentais na assistência ao parto, independentemente da classe social a que pertencesse a parturiente. Acresce que a posição social das parturientes definia de antemão o tipo de profissional que iria fazer o atendimento. Parteiras em posse de diplomas reconhecidos oficialmente, sem dúvida se destinavam às camadas sociais que dispunham de meios para pagar os serviços cuja qualificação provavelmente significava o encarecimento dos custos. Nos bairros populares, certamente a realidade era outra. Conforme testemunhado por Jacob Penteado, no Belenzinho, "naquele tempo, não havia parteiras diplomadas, apenas práticas, 'curiosas', mulheres que entendiam algo sobre o divino mistério da reprodução da espécie e ajudavam crianças a virem ao mundo". ${ }^{54}$ À exemplo do Belenzinho onde, por volta de 1910, um parto assistido por uma parteira prática custava dez mil réis, a realidade do Bexiga não devia ser muito diferente. Ali

ninguém se importava com a superpopulação. Tanto não se importava que o número de crianças aumentava a olhos vistos e não havia casa, maloca ou cortiço onde não existisse pelo menos uma mulher barriguda. [...] $\bigcirc$ parto era feito, na maioria das vezes, em casa por parteira e outras vezes já na Santa Casa. ${ }^{55}$

Mesmo correndo o risco de não ter abordado todas as formas de serviços informais (menores) existentes no bairro, que certamente envolveram outras categorias, espero ter fornecido um cenário das atividades mais significativas, aquelas que foram determinantes para o cotidiano dos moradores do Bexiga e dos bairros vizinhos. Reafirmo a importância de lançar luzes sobre uma realidade que até aqui se manteve obscura. Nesse sentido é que, acima de tudo, procurei dar visibilidade aos papéis representados pelos pequenos coadjuvantes da cena paulistana que, embora menores, foram fundamentais.

\section{DIVERSIDADE SOCIAL}

A representação do Bexiga como um bairro italiano ocupado pelas camadas mais pobres da população é resultado de uma narrativa construída ao longo do século XX e, como tal, sujeita a distorções. Se pretendemos nos aproximar mais efetivamente do objeto de estudo - o cenário e os atores correspondentes -, 
é necessário repensar as bases materiais e sociais sobre as quais esses agentes atuaram. Trata-se de um bairro que, em suas origens, foi prioritariamente ocupado pelas camadas médias e baixas da população, oriundas de contextos étnicos e culturais diversos. Mas não somente, pois ainda que em número reduzido, ali também encontramos chefes de família cujas especializações profissionais indicam o pertencimento às camadas altas da sociedade paulistana, tais como médicos, advogados, negociantes bem-sucedidos etc.

Embora o panorama traçado até aqui tenha elucidado algumas das funções desempenhadas pelo bairro no cenário mais amplo da cidade, resta uma questão fundamental acerca desse espaço: quem eram seus moradores e como transcorria sua vida no dia a dia daquele cenário?

Os Boletins de Ocorrência do Posto Médico da Assistência Policial, integrantes do Fundo da Secretaria da Segurança Pública do Arquivo Público do Estado de São Paulo (Apesp), ${ }^{56}$ se mostraram fontes fundamentais para a busca de respostas a essas perguntas. Esse corpus documental é particularmente importante por fornecer uma multiplicidade de dados e detalhes sobre a vida cotidiana dos moradores do bairro - nome, cor, nacionalidade, idade, filiação lquando se tratava de menores de dezoito anos), profissão, endereço e motivação da ocorrência. Ao informar nacionalidades, profissões desempenhadas pelos atores sociais, sua localização no espaço e as causas das ocorrências, tais documentos possibilitam a remontagem de certos perfis típicos do bairro. Além disso, através dos Boletins é possível aquilatar a presença dos afrodescendentes no bairro, aparentemente indistintos entre nomes e sobrenomes de raiz brasileira e portuguesa, bem como dar espacialidade aos seus lugares de moradia e trabalho. Já a localização dos endereços indicados nos Boletins, além de viabilizar a espacialização e quantificação dos moradores por domicílio, sugerindo inclusive a presença de habitações coletivas, permite estimar a densidade populacional aproximada de quase todas as ruas, e em certos casos foi possível identificar praticamente todos os moradores na extensão da mesma via.

Os Boletins de Ocorrência não respondem tudo, mas fornecem indícios a serem aprofundados. A partir das linhas e entrelinhas dos processos-crimes é possível reconstituir a trajetória de certos indivíduos ${ }^{57}$ e, numa etapa posterior, construir o perfil de determinado tipo de morador do Bexiga - de outra forma seria quase impossível imaginar a vida cotidiana no bairro e suas formas de sociabilidade. Instalado junto das delegacias de polícia, o posto médico era responsável pelos primeiros socorros às vítimas de todo tipo de problema: "mal súbito", doenças, embriaguez, ferimentos decorrentes de acidentes no trânsito, desastres, agressões, tentativas de suicídio etc. Os atendimentos podiam ser feitos na residência do
56. Boletins de Ocorrência (1911-1912, 1914-1915, 1925).

57. As informações contidas nos Boletins de Ocorrência foram enriquecidas e complementadas pelos acervos dos jornais $O$ Estado de São Paulo (19001931, 1936, 1938) e Diário Oficial do Estado de São Paulo (1900-1931). 
vitimado, na rua ou ainda na delegacia mais próxima do local da ocorrência, o que parece ter sido mais comum, pois inúmeras ocorrências relatam o atendimento após uma chamada telefônica à delegacia. A partir do primeiro atendimento, se o caso fosse simples, a pessoa retornava à residência, porém, quando se tratava de algo mais grave, a pessoa era encaminhada à Santa Casa ou eventualmente a um hospital particular. Já nos casos em que o problema se originava do estado de embriaguez, o encaminhamento da vítima era para o "xadrez" mais próximo.

Tratando-se de atendimentos realizados por um órgão de segurança pública, está claro que, mais do que a prestação de socorro médico à população, a intenção da instituição era policiar o comportamento social no espaço urbano e, para tanto, o fichamento das vítimas era essencial. Assim, é necessário relativizar e historicizar tanto o discurso de pacientes, quanto aquele dos agentes médicopoliciais. Em relação aos primeiros, em diversas ocasiões percebe-se que ao fornecerem as informações solicitadas, intencionalmente ou não, mentiam sobre sua condição. Quanto aos agentes médico-policiais, a "alteração" mais frequente se refere à identificação racial, pois, a depender do ponto de vista de quem fazia as anotações, a mesma pessoa podia ser classificada como negra, parda ou mesmo branca. Nunca é demais lembrar que a classificação implicava um certo juízo fruto da subjetividade dos atendentes, e tais juízos não estavam isentos de preconceitos em face do caráter racial e étnico dos envolvidos. Certamente a classificação das ocorrências oscilava ao sabor do sistema de valores culturais e ideológicos dos agentes públicos.

A pesquisa abrangeu três períodos, selecionados de forma mais ou menos aleatória, a título de constituição de uma amostragem. Num primeiro momento, elegi os atendimentos médicos junto às Delegacias de Polícia, de outubro de 1911 (quando do início do procedimento de escrituração das ocorrências) a maio de 1912. Em seguida, abordei todo o ano de 1914, além do mês de janeiro de 1915, quando essa forma de atendimento médico já parecia ter sido incorporada pela população e a instituição policial já se mostrava mais organizada em relação aos diferentes tipos de ocorrência. Finalizei a pesquisa investigando o ano de 1925. De toda maneira, o questionamento dessa fonte documental deve ser um procedimento constante a fim de evitar a transmissão de visões estereotipadas acerca de determinada realidade, risco a que o pesquisador está invariavelmente sujeito.

Encarando toda a extensão do bairro, a primeira evidência é a alta concentração de pessoas em algumas ruas, fato que se mantém em praticamente todo o período investigado. Na "área nobre" (com 174 ocorrências), a rua 
Asdrúbal do Nascimento e a avenida Brigadeiro Luís Antônio parecem ter sido as vias preferidas dos moradores. No caso da avenida, trata-se de uma via com percurso longo entre o Largo do Riachuelo e a avenida Paulista, enquanto o trecho da rua Asdrúbal do Nascimento identificado como parte do Bexiga limita-se entre - Largo do Riachuelo e a própria avenida. No loteamento original (com 1287 ocorrências) se destacaram as ruas Santo Antônio, Rui Barbosa, Conselheiro Ramalho e Major Diogo, e três delas, as últimas, parecem ter disputado a preferência dos moradores do bairro, certamente pela presença das linhas de bonde, então o único meio de transporte coletivo disponível. Se no loteamento original do Bexiga a densidade populacional supera quaisquer expectativas, a presença de moradores do Vale do Saracura nos anos 1910 e 1920 mostra-se curiosamente escassa. Particularmente em 1925, quando houve um maior número de ocorrências, o socorro aos moradores da área limitou-se a 49 pessoas, representando pouco mais de $6 \%$ do total de 765 atendimentos registrados no bairro naquele ano, o que não é de espantar, sobretudo porque nessa área se verificavam pouquíssimas construções em relação à grande área vazia no entorno do córrego com o mesmo nome.

Da identificação espacial das pessoas atendidas no posto médico, segundo os endereços fornecidos pelas vítimas, decorreu outra informação importante: a localização de algumas das possíveis habitações coletivas do bairro.

Na dificuldade em precisar critérios para a definição de habitações coletivas e cortiços, o Código Sanitário de São Paulo, de 1894, pode fornecer alguns parâmetros mais objetivos para pensar essas tipologias no Bexiga. $\bigcirc$ capítulo III desse documento parece prever a construção de novos edifícios destinados a habitações coletivas, estabelecendo parâmetros como, por exemplo, a localização fora do perímetro urbano, o que envolveria os novos loteamentos nos arrabaldes da cidade. $\bigcirc$ capítulo $V$ indica cuidados com a construção de "casas operárias" e "vilas" em geral. Certamente prevendo a utilização dessas casas como cortiços, o capítulo se inicia com a sua proibição, além de indicar a necessidade de destruir as existentes. Aqui observa-se certa confusão entre o que seria cortiço, casa de pensão e habitação para as camadas pobres, sobretudo no artigo que proíbe a subdivisão de "grandes casas". Como distinguir a "casa de pensão" do "cortiço", já que ambos eram ocupados por um número variado de indivíduos? E ainda, como delimitar o número de pessoas que podiam viver num ou noutro tipo de construção? De acordo com o artigo 127 do capítulo IV, sobre os "hotéis e casas de pensão", "o número de locatários deverá ser proporcional à capacidade do edifício e não deverão ser permitidos menos de 14 metros cúbicos de espaço para cada indivíduo, nos aposentos dos locatários". Já o artigo 144 do capítulo 
58. Obras Particulares (1914, grifo nosso).

59. Sevcenko (1992, p. 129132).
V, sobre as "habitações das classes pobres", indica que "deve ser determinada a lotação dessas casas, não sendo permittidos aposentos de dormir com menos de 14 metros cubicos livres para cada indivíduo". As orientações legais acerca das dimensões mínimas para cada pessoa são as mesmas nos dois tipos de moradia e não deixam margem a dúvidas. $\bigcirc$ mesmo se pode dizer sobre o número de pessoas permitido num e noutro caso. Aparentemente, tudo dependia das dimensões dos prédios, se ocupados por "hotéis", "casas de pensão" ou pelas "classes pobres".

De qualquer modo, do ponto de vista do Código todas essas modalidades de moradia parecem implicar a ocupação por pessoas pobres. Excetuando-se as casas de pensão, que poderiam ser ocupadas por pessoas de camadas sociais variadas, cortiços, casas operárias e vilas deviam ficar fora do perímetro urbano. A intenção de segregação é muito clara, o que não fica clara é a definição de cortiços, casas de pensão e habitações das camadas pobres, assim como as diferenças entre os tipos de habitação coletiva. De maneira geral, foram esses os pontos do Código Sanitário utilizados para a identificação e análise dos cortiços no bairro do Bexiga. Ali percebe-se o quanto essas categorias se misturavam e se confundiam, demonstrando que também para a municipalidade foram pontos obscuros, nem sempre interpretados de forma objetiva.

A partir da década de 1910 ficou evidente a tendência, se não de eliminar os cortiços, de evitar que aumentassem de tamanho, o que fica bastante explícito no caso relatado a seguir. Em 1914 o pedido de licença para acréscimo de cozinha, latrina e tanque à casa localizada à rua Rui Barbosa n 131, cujo requerimento estava em nome de José Maria Passalacqua, gerou um longo processo, que se estendeu até ser finalmente indeferido, em 1917. Nessa ocasião, o parecer do engenheiro Arthur Saboya deixava claro que se tratava de "aumento de cortiço existente, em desacordo com o Código de Posturas, Artigo 20, não sendo pela lei n ${ }^{\circ}$ 1788, Art. $5^{\circ}$, então vigente, tolerados novos cortiços e, consequentemente, aumento dos existentes" ${ }^{58}$ Esse processo bastante complicado indica que, por mais que as autoridades municipais se esforçassem dali em diante, a luta entre poder público, proprietários e moradores se intensificaria.

Ao analisar a São Paulo dos anos 1920, Nicolau Sevcenko ${ }^{59}$ chama a atenção para o fato de o crescimento da cidade ter sido desproporcionalmente maior do que as possibilidades de controle por parte do poder público. Conforme Sevcenko, apesar do empenho demonstrado pela municipalidade em 
controlar o crescimento urbano desenfreado, através da ação da Diretoria de Obras e da Inspetoria Sanitária, fatores como limites orçamentários e a estrutura administrativa enxuta da municipalidade dificultaram e até impediram quaisquer reações contra a pressão exercida pelas manobras especulativas e contra o descaso por parte daqueles que detinham o controle político e econômico da cidade. A conjugação desses fatores trouxe como consequência funesta a ocupação desenfreada dos espaços possíveis. Enquanto os novos loteamentos envolviam regiões esparsas pela cidade e distantes do Centro, extensas áreas intermediárias foram propícias à especulação mais agressiva. Nesse contexto de demanda por moradias é que as possibilidades de uso do solo urbano nas áreas mais próximas do Centro foram exploradas exaustivamente, envolvendo todas as formas habitacionais que permitissem a presença de um maior número de pessoas: casas de cômodos, pensões e cortiços. E foi esse o cenário vivenciado pelos inúmeros personagens que passaram pelos atendimentos médicos nos postos policiais da cidade.

De toda maneira, creio que o agrupamento de pessoas, certamente com características culturais diversas, deva ser atribuído, antes de mais nada, à falta de recursos financeiros que garantissem a privacidade individual ou familiar. Nesse quesito, cabe uma rápida digressão sobre as razões que levam as pessoas a dividir seu espaço com outras de nacionalidades e valores culturais diferentes. Partindo do exemplo dos italianos, é sabido que o Bexiga foi o destino de uma quantidade relevante de imigrantes oriundos da Calábria, região pobre situada na Itália Meridional, que vieram sozinhos ao Brasil ou em família. ${ }^{60}$ Frequentemente sós, a divisão de um teto com desconhecidos era uma estratégia de sobrevivência e poupança de recursos financeiros. Mesmo em família, os parcos recursos trazidos na viagem exigiam gastos mínimos até que pudessem se estabilizar profissional e financeiramente na cidade, para o que as pensões e os cortiços se mostraram a opção viável, ao menos temporariamente.

Na Tabela 2, a partir dos endereços fornecidos pelos Boletins de Ocorrência procurei demonstrar como as possíveis habitações coletivas se distribuíram pelas ruas do bairro.

Com exceção do Albergue Noturno - instituição especialmente destinada a abrigar pessoas sozinhas e destituídas de moradia, na rua Asdrúbal do Nascimento -, nos endereços elencados residiam mais de três pessoas de sobrenomes diferentes. Nesses casos específicos verifica-se que, de uma maneira geral, conviviam brancos e negros, brasileiros e imigrantes e, embora os italianos fossem os mais frequentes, também foram identificadas pessoas originárias de outros países (portugueses, espanhóis, franceses, alemães e iugoslavos).
60. Cf. Alvim (1986); Lanna (2011). 


\begin{tabular}{|c|c|c|c|c|c|}
\hline $\begin{array}{c}\text { ÁREA DE } \\
\text { REFERÊNCIA }\end{array}$ & LOGRADOURO & $\begin{array}{l}1911- \\
1912\end{array}$ & $\begin{array}{l}1914- \\
1915\end{array}$ & 1925 & Total \\
\hline \multirow{3}{*}{$\begin{array}{l}\text { ÁREA } \\
\text { "NOBRE" }\end{array}$} & $\begin{array}{l}\text { Asdrúbal do Nascimento } \\
\text { (Albergue Noturno) }\end{array}$ & - & 1 & - & 1 \\
\hline & Brigadeiro Luís Antônio & - & 1 & - & 1 \\
\hline & Maria Paula & - & 1 & - & 1 \\
\hline \multirow{11}{*}{$\begin{array}{l}\text { LOTEAMENTO } \\
\text { ORIGINAL }\end{array}$} & Conselheiro Ramalho & - & 2 & 2 & 4 \\
\hline & Humaitá & & 1 & & 1 \\
\hline & Travessa Jacareí (Vila Barros) & - & - & 1 & 1 \\
\hline & Jaceguai & - & 1 & - & 1 \\
\hline & Major Diogo & - & 2 & 2 & 4 \\
\hline & Rui Barbosa & - & 3 & 2 & 5 \\
\hline & Santo Amaro (Vila Barros) & - & - & 1 & 1 \\
\hline & Santo Antônio & 1 & 2 & 3 & 6 \\
\hline & São Domingos & 1 & - & - & 1 \\
\hline & Sol/Dr. Luís Barreto & - & 1 & - & 1 \\
\hline & Treze de Maio & - & 3 & 4 & 7 \\
\hline SARACURA & $\begin{array}{l}\text { Saracura Grande/Almirante } \\
\text { Marques Leão }\end{array}$ & - & - & 2 & 2 \\
\hline TOTAL & & 2 & 18 & 17 & 37 \\
\hline
\end{tabular}

Tabela 2 - Ocorrência de possíveis habitações coletivas pelas do bairro, por período e área analisados. Fonte: Boletins de Ocorrência.

Infelizmente, diante da vasta área ocupada pelo Bexiga, os números apresentados na Tabela 2 representam apenas três anos de análise, mostrandose insignificantes e inviabilizando uma avaliação mais efetiva das habitações coletivas existentes no bairro. Com certeza, trata-se de uma questão a ser aprofundada a partir de uma análise que envolva uma sequência temporal mais ampla, de maneira a acompanhar a evolução desse tipo de moradia. Porém, ainda que restrita, a amostra analisada se presta a identificar parte da diversidade étnica e racial existente no Bexiga; diversidade essa bem representada na foto do cortiço na rua Conselheiro Ramalho $n^{\circ}$ 247-A, onde crianças negras e brancas posam para o fotógrafo, algumas delas, talvez, filhas de imigrantes europeus. 


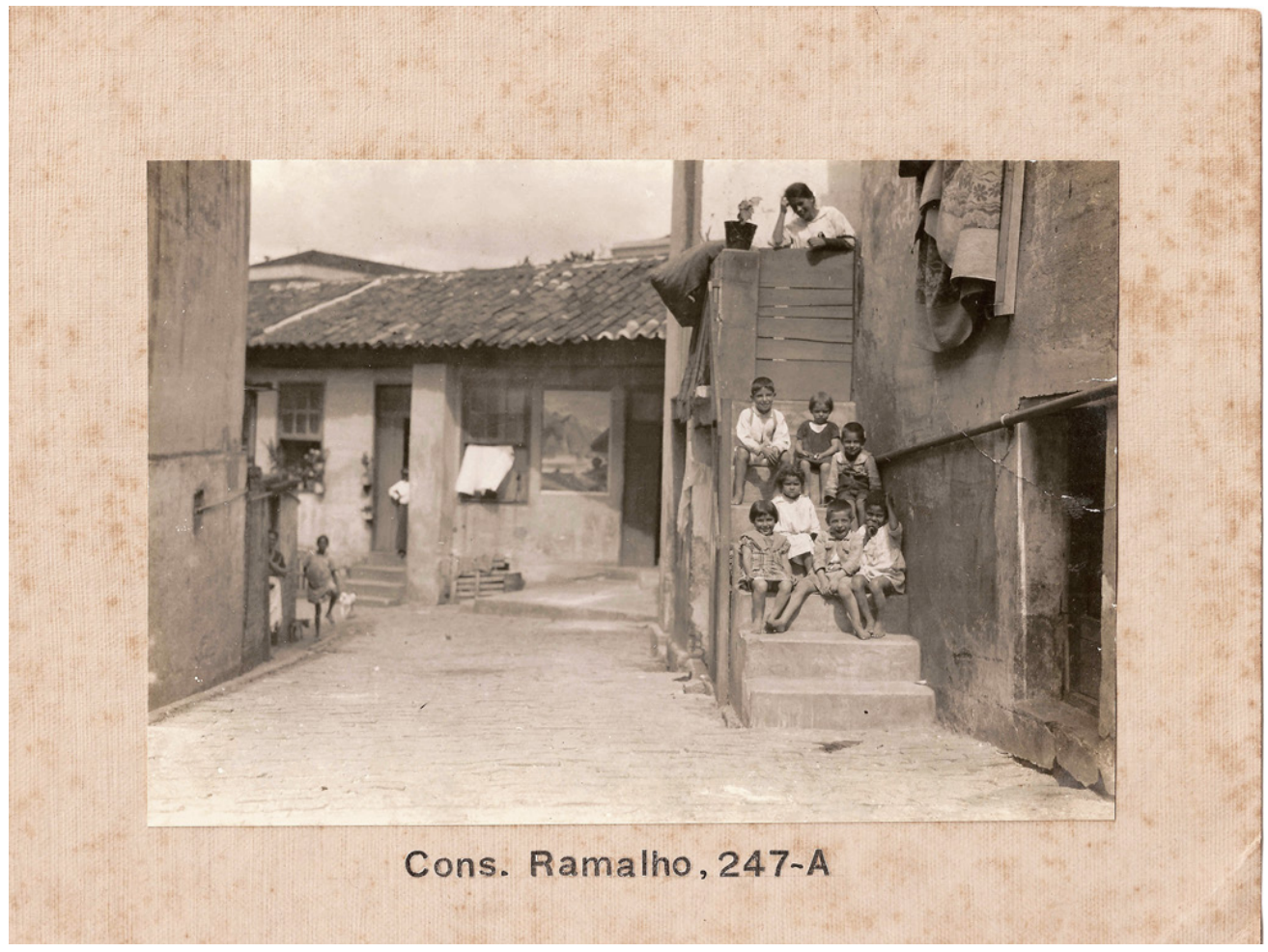

61. Lanna (2011, p. 117127).

Figura 9 - Cortiço localizado à rua Conselheiro Ramalho. Autoria desconhecida, s/d. Fonte: Acervo do Centro de Memória da Saúde Pública, Faculdade de Saúde Pública da Universidade de São Paulo.

\section{DIVERSIDADE ÉTNICA}

Quando pensamos na imigração de pessoas oriundas de diferentes países, devemos levar em conta que a adaptação e integração ao novo ambiente é um processo com duração difícil de mensurar. É plausível supor que as pessoas se agrupem por laços de solidariedade segundo bagagens socioculturais comuns, lugares de procedência e vínculos familiares pregressos, ${ }^{61}$ o que pode implicar a reprodução de valores originais do grupo por gerações. Diante dessa perspectiva, ao contabilizar os indivíduos oriundos de países diversos, como Itália, Portugal, Espanha etc., busquei explorar os dados fornecidos pelos Boletins de Ocorrência de maneira a averiguar a dimensão de seus possíveis desdobramentos. Num primeiro momento identifiquei o número exato de pessoas de cada nacionalidade, sobretudo os italianos. Posteriormente, no caso dos italianos, agrupei os indivíduos daquela nacionalidade àquelas que, supostamente, seriam as primeiras gerações nascidas no Brasil. Um procedimento semelhante foi utilizado em relação aos 
brasileiros brancos e afrodescendentes. Oficialmente ambos são definidos como brasileiros, mas as diferenças culturais, assim como as cargas emocionais ditadas por sua história particular os distinguem dos habitualmente definidos como "nacionais". Dessa maneira, acredito ter obtido um panorama, ainda que aproximado, da ocupação do bairro do Bexiga por italianos, brasileiros e pessoas de outras nacionalidades.

\begin{tabular}{|c|c|c|c|c|c|c|}
\hline $\begin{array}{l}\text { ETNIAS E } \\
\text { NACIONALIDADES }\end{array}$ & \multicolumn{2}{|c|}{$1911-12$} & \multicolumn{2}{|c|}{$1914-15$} & \multicolumn{2}{|c|}{1925} \\
\hline ITALIANOS & 57 & \multirow{2}{*}{73} & 179 & \multirow{2}{*}{292} & 133 & \multirow{2}{*}{325} \\
\hline $\begin{array}{l}\text { ÍTALO-BRASILEIROS } \\
\text { (SUPOSTOS) }\end{array}$ & 16 & & 113 & & 192 & \\
\hline $\begin{array}{l}\text { BRASIIEIROS/ } \\
\text { AFRODESCENDENTES }\end{array}$ & 50 & 91 & 95 & 205 & 128 & 308 \\
\hline BRASILEIROS/NACIONAIS & 41 & & 110 & & 180 & \\
\hline PORTUGUESES & 7 & 7 & 84 & 84 & 66 & 66 \\
\hline ESPANHÓIS & 4 & 4 & 19 & 19 & 27 & 27 \\
\hline
\end{tabular}

Tabela 3 - Distribuição das etnias e nacionalidades identificadas no bairro do Bexiga nos três períodos investigados. Fonte: Boletins de Ocorrência.

A Tabela 3 - com exceção dos anos 1911 e 1912, quando o número de nacionais e afrodescendentes superou o de italianos - confirma a preponderância destes sobre os demais. Contudo, quando se calcula a relação percentual entre cada grupo étnico e o total de ocorrências de cada período, verifica-se que as diferenças entre a quantidade de italianos e brasileiros no bairro são menos expressivas: 40,56\% e 50,56\% respectivamente no primeiro período analisado; $47,18 \%$ de italianos e 33,12\% de brasileiros entre 1914 e 1915; e 42,38\% de italianos e 40,16\% de brasileiros em 1925. Já em relação às demais nacionalidades, destacam-se portugueses e espanhóis, com presença igualmente significativa no bairro nos dois últimos períodos. 
De acordo com dados fornecidos pela Empresa Paulista de Planejamento Metropolitano (Emplasa), três anos antes da Proclamação da República os italianos formavam o maior contingente de estrangeiros na cidade (80,22\%), seguidos dos portugueses e alemães (que correspondiam a 11,98\% dos habitantes da capital paulista). Já em 1920, em plena vigência da Primeira República, a população italiana se manteve como a maior colônia estrangeira em São Paulo, perfazendo 15,84\% da população total. Na sequência, vinham os portugueses (1 1, 19\%), os espanhóis $(4,31 \%)$ e os germânicos $(3,07 \%)$ - todos em meio a 372.376 brasileiros $(64,46 \%)$, numa população total de 577.621 habitantes. ${ }^{62}$

A partir dos dados fornecidos pela Emplasa ${ }^{63}$ e pelos Boletins de Ocorrência já citados, elaborei a Tabela 4 com a relação de brasileiros e estrangeiros moradores do Bexiga, de modo a obter um índice aproximado de sua participação na composição da população paulistana.

\begin{tabular}{|l|c|c|}
\hline \multicolumn{1}{|c|}{ NACIONALIDADES } & TOTAL & $\%$ \\
\hline BRASILEIROS (NACIONAIS E AFRODESCENDENTES) & 308 & 40,16 \\
\hline ITALIANOS (NATOS E DESCENDENTES) & 325 & 42,38 \\
\hline PORTUGUESES (NATOS) & 66 & 8,60 \\
\hline ESPANHÓIS (NATOS) & 27 & 3,52 \\
\hline OUTRAS & 15 & 1,95 \\
\hline $\begin{array}{l}\text { SíRIOS, JAPONESES, DESCENDENTES OUTRAS NACIONALL- } \\
\text { DADES (NATOS) }\end{array}$ & 24 & 3,13 \\
\hline NÃO CONSTA & 2 & 0,26 \\
\hline TOTAL & 767 & $100 \%$ \\
\hline
\end{tabular}

Tabela 4 - Dados comparativos da participação de brasileiros e estrangeiros moradores do bairro do Bexiga (1925) em relação à composição da população paulistana em 1920.

Os Boletins de Ocorrência, além de corroborarem as análises de autores que versaram sobre a presença negra no Bexiga, ${ }^{64}$ permitem acrescentar à presença já sabida dos afrodescendentes no Saracura a dos portugueses, fato constatado por Armandinho do Bixiga, morador no bairro desde o nascimento até a sua morte, em 1994. De acordo com Armandinho, embora o Bexiga possuísse uma maioria de italianos, na região do Saracura "se localizavam muitos negros e portugueses". ${ }^{65}$
62. Emplasa (2001).

63. Emplasa (2001, v. 2, p. 52).

64. Koguruma (2001); Wissenbach (1989).

65. Moreno (1996, p. 87-88, grifo nosso). 
Os Boletins de Ocorrência são fontes privilegiadas para aferir relações sociais no cotidiano do bairro, permitindo inclusive vislumbrar sinais de tensões e conflitos entre os diferentes grupos ali residentes. Nunca é demais lembrar que o convívio social entre brasileiros e imigrantes foi marcado pela questão políticoideológica da intenção de branqueamento da raça, fato já bastante analisado por diversos autores, sob diferentes pontos de vista, como Paulo Cesar Xavier Pereira ${ }^{66}$ e Carlos José F. dos Santos. ${ }^{67}$ Acredito que o imigrante, consciente ou inconscientemente, tenha incorporado esse ideário na medida em que ele próprio representava o instrumento essencial para o suposto êxito daquela política deliberada imposta na chamada Primeira República (1 889-1930).

Contudo, apesar da posição aparentemente privilegiada que o imigrante ocupava, sua inserção na sociedade brasileira não foi assim tão fácil, sobretudo em face do recente passado escravista que mantinha uma série de preconceitos ainda muito vivos e arraigados no imaginário coletivo. Se, de um lado, o imigrante era a força de trabalho necessária no momento de afirmação/inserção do país num processo econômico mais amplo, num universo onde o trabalho pesado era um estigma atrelado à imagem dos escravos, por outro lado, qualquer movimento seu que contrariasse as expectativas do Estado e dos patrões era fortemente reprimido, fato comprovado pela reação às greves realizadas no decorrer dos anos 1910.

Em momentos de crise econômica e social, quando as possibilidades de sobrevivência escasseiam, as diferenças culturais entre os diversos grupos sociais tendem a se manifestar sob a forma de conflitos e tensões. Dessa maneira, as relações sociais no Bexiga e em outros bairros da cidade ocupados pelas camadas médias e baixas da população foram marcadas por instabilidade constante: em tempos difíceis, qualquer motivo seria suficiente para desencadear tensões e conflitos. As fontes investigadas confirmam tais ocorrências, que se manifestavam de diversas formas: na relação entre inquilinos e proprietários, na disputa por clientela, nas brigas e bebedeiras nos botequins e nas ruas.

A seguir, relato um caso bastante ilustrativo. Entre dezembro de 1906 e fevereiro de 1907 correu um processo na Sessão de Polícia e Higiene do município contra o comerciante de secos e molhados Alfonso Montebello e o servente de pedreiro Paschoal Pécora, sob a alegação de que o primeiro "negociava com quitanda" e o segundo exercia o ofício de "padeiro", sem que houvesse o recolhimento das taxas cabíveis. Montebello, em resposta ao aviso recebido em 14 de dezembro de 1906, afirmou que, sendo "negociante de secos e molhados, 
residente à rua Santo Antônio 254, atualmente não pediu licença de quitanda como consta do aviso enviado por V. Excia. à 14 do corrente". Diz ainda que "seu cunhado Paschoal Pecora foi sempre servente de pedreiro e sua senhora e filha são costureiras de uma loja turca, não exercendo o cargo de padeiros conforme o aviso junto: tendo apenas para uso da família um pequeno forno de $1 \mathrm{~m}$, mais ou menos de circunferência". Cerca de um mês depois, o "guarda fiscal Cunha", responsável pela inspeção do negócio, encaminhou à chefia da sessão "um abaixo assinado que me foi apresentado em meados deste mês e organizado pela pessoa que deu denuncia, cujos signatários afirmam o contrário do que alega o requerente". Nesse documento os peticionários, encabeçados por João Ferraciano, declaram "que o Sr. Alfonso Montebello negociou com quitanda, assim como o Sr. Paschoal Pecora, com forno de padaria durante o ano p.p. na rua Manoel Dutra e Largo São Manoel sem terem satisfeito os impostos, com prejuízo de outros que legalmente pagaram suas licenças". 68 Ocorre que o armazém de João Ferraciano69 localizava-se na rua Santo Antônio n 242A, a poucos metros do negócio de Alfonso Montello, no nº 254. Assim, ainda que o argumento dele e dos demais signatários do documento acerca do não pagamento de impostos seja perfeitamente válido, é evidente que se tratava de um caso de disputa pela clientela.

Um caso semelhante, envolvendo o exercício de atividades supostamente sem licença da Prefeitura, foi aquele de José Tosto. Em 24 de outubro de 1908, um abaixo-assinado por "diversos negociantes que pagam imposto" foi encaminhado à Sessão de Polícia e Higiene, alertando que o estabelecimento localizado "na rua Major Diogo 49 vende vinho sem licença nem da câmara municipal e nem da alfandiga (sic) por isso prevenimos a V.S. formar (?) procedimentos nessa casa tem jogos também. Esperamos que V.S. tomara procedimentos". No entanto, o parecer emitido pela Secretaria em 31 de outubro de 1908, ao dizer que "o negócio dos proprietários (?) e José Tosto está lançado como botequim e jogo de bolas", deixa claro que o estabelecimento funcionava dentro dos parâmetros legais, não cabendo quaisquer medidas punitivas. Infelizmente o processo não cita os nomes dos envolvidos, não sendo possível identificar os interesses e que tipo de negócio exerciam, porém evidencia a intenção de denegrir o nome de José Tosto. Se isso realmente aconteceu, os esforços foram vãos, pois a julgar pelos exemplares do Almanak Laemmert, a casa de secos e molhados de Tosto não só se manteve como prosperou, tendo funcionado pelo menos até 1923.

Os conflitos entre moradores do Bexiga também podiam se manifestar na relação entre inquilinos e proprietários, como ocorreu com Salvador Bonacorso. Em 8 de março de 1914, o jovem Bonacorso, gazista de profissão e residente à rua Santo Amaro n 72, em cômodo "sublocado por Manoel Pereira", 70 passou por
68. Fundo Secretaria Geral, Grupo Seção de Polícia e Higiene, Série Fiscalização (1906).

69. Conforme as solicitações de licença encaminhadas à Diretoria de Obras por João Ferraciano, em 10 de janeiro de 1907 , e por Alfonso Montebello, em 11 de maio de 1907 (Obras Particulares, grifos nossos).

70. Boletins de Ocorrência (1914). 
71. O Estado de São Paulo (1914).

72. Moreno (1996, p. 88). atendimento no posto médico com "ferimento no punho direito, por agressão à faca". De acordo com a matéria publicada no Estado de São Paulo, após meses de atraso no pagamento dos aluguéis por parte de Salvador, Manoel Pereira decidiu trancar o quarto do inquilino, impedindo-o de ali entrar. Salvador, ao chegar, arrombou a porta, ao que Manoel reagiu desferindo-the um golpe de faca. A ocorrência não teve maiores consequências, já que após o atendimento Bonacorso foi encaminhado de volta a sua residência. ${ }^{71}$

Menos evidentes são os conflitos originados de relações inter-raciais, mas existiam. Armandinho do Bixiga fornece algumas pistas, se não de conflitos abertos, pelo menos de tensões expressas em manifestações preconceituosas dos italianos em relação aos negros. Logo após negar a existência de preconceito de brancos contra negros, ele diz: "Agora, tem uma coisa importante: se o filho de um italiano fosse casar com uma negra, eu acho que o pai matava ele. [...] Eu não conheci um filho de italiano que casou com uma negra. Não tinha esse negócio" 72

Um dado revelador fornecido pelas ocorrências policiais se refere a uma suposta predisposição dos afrodescendentes a se envolver em conflitos - mas, contrariamente ao que se poderia supor, somente 55 indivíduos, entre negros e pardos, entraram em desavenças que resultaram em agressão física, representando apenas 23\% do total de 237 ocorrências qualificadas como crimes. Por outro lado, entre todos os envolvidos em crimes, apenas 65 pessoas $(27,42 \%)$ não apresentaram indicação de algum tipo de ocupação; os demais 172 indivíduos exerciam algum tipo de atividade produtiva (72,58\% do total de pessoas). A partir desses números, constata-se que qualquer que seja o grau de violência dos atores envolvidos nessas ocorrências, não se tratava de "vadios ou desocupados", mas de gente que tinha uma rotina de trabalho e morava em casas unifamiliares ou em habitações coletivas e/ou cortiços. Aliás, foram relativamente poucos os usuários das supostas habitações coletivas, apenas $28,27 \%$ dos envolvidos em crimes (67 pessoas).

Por fim, cabe destacar que a confrontação dos Boletins de Ocorrência com outras fontes primárias permite vislumbrar algo mais acerca dos moradores do Bexiga. A identificação de raros elementos entre as pessoas que comprovadamente possuíam propriedades ou negócios no Bexiga vem comprovar a suposição acerca da diversidade social do bairro. Se de um lado havia negociantes em uma situação estável, que thes permitia sobreviver a partir de seus próprios negócios por anos a fio, de outro havia um contingente considerável de moradores que desempenharam funções menores, marcadas pela precariedade e sobretudo pela instabilidade. Instabilidade essa que fica evidente quando verificamos a flutuação constante da população atendida nos postos médicos da cidade, seja no que se refere à frequente 
mudança de endereços e empregos, seja entre aqueles que permaneceram no bairro ao longo dos anos. Dentre os 1566 casos de atendimento médico analisados nos três períodos, com exceção das pessoas identificadas nos almanaques, ou que com elas possuíam laços familiares comprovados, somente quatro indivíduos conseguiram permanecer no bairro por mais de um ano: dois entre 1912 e 1914, e 2 entre 1914 e 1925. Nesse meio tempo, mudaram alguns endereços e mudaram algumas ocupações. Mas, sobretudo, desapareceram muitas pessoas!

\section{CONSIDERAÇÕES FINAIS}

Enquanto o processo de transformação modernizadora se operava com a consolidação dos novos espaços/bairros e suas correspondentes funções, no decorrer do século XX assistimos à construção de uma certa história na qual alguns estereótipos foram dados como traços determinantes da metrópole: a cidade ordenada llegal e espacialmente) segundo preceitos ideais, visto que resultante de um supostamente correto modelo europev; a cidade convenientemente branqueada pela presença do imigrante (também) europeu, principalmente o italiano; a cidade cosmopolita, onde a coexistência de diferentes culturas supostamente the conferia um caráter democrático e, por extensão, oportunidades iguais para todos; a cidade dinâmica, onde o valor do trabalho, definido pela máxima "São Paulo não pode parar", funcionaria como o motor propulsor do progresso do país; enfim, uma cidade moderna representada pelo espaço público adequado às suas (novas) necessidades e pela arquitetura imponente de edifícios públicos e privados. Contudo, a manutenção desses predicados no imaginário urbano tem como consequência funesta a perpetuação de preconceitos geradores de práticas sociais excludentes. Ao mesmo tempo, e até em consequência disso, tais atributos alimentam outro processo funesto: o ressentimento (inconsciente) da maioria daqueles que estão envolvidos nessa lógica perversa de exclusão, ${ }^{73}$ as camadas mais pobres da população.

O legado transmitido por essa historiografia ao imaginário contemporâneo consagrou o Bexiga como um espaço essencialmente popular, cujos habitantes, majoritariamente italianos, viviam nos inúmeros cortiços construídos ao longo de suas ruas. Ainda que sejam poucos os trabalhos a abordarem a história do bairro, a imagem fornecida por eles frequentemente confirma, se não todos, quase todos esses estereótipos. ${ }^{74}$ Entre os autores que tomaram o Bexiga como objeto de análise destacam-se os trabalhos de Nádia Marzola e do memorialista Haim Grünspun, publicados no mesmo ano.
73. Bresciani; Naxara (2004, p. 9-11).

74. Cf. Gontier (1990); Grünspun (1979); Lucena (1983); Marzola (1979); Moreno (1996). 
75. Marzola (1979, p. 16, grifo nosso).

76. Marzola (1979, p. 16).

77. Grünspun (1979, p. 37, grifo nosso).

78. Castro (2008); Kogurama (2001); Wissenbach (1989).
Marzola, ainda que não tenha se proposto a realizar "um trabalho 'científico', mas "apenas uma coletânea de tudo o que foi dito e escrito a respeito da Bela Vista"75 - e talvez até por isso -, referendou lugares-comuns acerca do bairro. É o que demonstram as afirmações feitas pela autora já na introdução do livro, acerca da "homogeneidade das casas" e sobre a Bela Vista ter sido, "ao lado do Brás, o bairro dos italianos". ${ }^{76} \bigcirc$ termo homogeneidade ali utilizado coloca em destaque um conceito que no decorrer do trabalho confere a todas as instâncias constitutivas do bairro um caráter de uniformidade social, étnica, arquitetônica e funcional.

Embora essas características tenham permeado a realidade do bairro, o resultado de minhas investigações demonstra que nunca foram realmente definidoras daquele espaço. Quanto às funções urbanas exercidas no Bexiga, há uma profusão de atividades produtivas envolvendo manufaturas, comércio diversificado e prestação de serviços, cuja utilidade certamente extrapolou os limites e as necessidades do bairro. Já pensando nas ocupações profissionais dos moradores do bairro, de acordo com Haim Grünspun,

Os homens do Bexiga em sua maioria não tinham vínculos empregatícios como os operários nas fábricas da Lapa, Brás, Mooca ou Bom Retiro. Nem queriam muito este vínculo; portanto, passavam longos dias sem trabalho. Além dos ótimos artesãos, que também passavam longos períodos de ócio em seu trabalho, os homens do Bexiga eram igualmente tarefeiros. ${ }^{77}$

Diferentemente do que o autor sugere, encontrei homens e mulheres engajados no mercado de trabalho, não apenas no próprio bairro, mas também em outras áreas da cidade. Tratavam-se sobretudo de ocupações não qualificadas, caso dos trabalhadores da construção civil, dos prestadores de serviços de transporte, dos serviços domésticos etc. Além disso, não foram tão raros os exemplos de profissionais liberais que utilizaram o bairro como local de moradia, enquanto trabalhavam nas ruas centrais da cidade.

Realmente, a identificação dos usuários das casas construídas no bairro e dos negociantes ali radicados, assim como dos usuários dos serviços médicos associados às delegacias de polícia, confirmou o predomínio do italiano sobre as demais etnias, sem, contudo, ignorá-las. Embora liderada pela comunidade italiana, a composição étnica do bairro envolveu um número significativo de portugueses, espanhóis, sírios e libaneses, mas também, e principalmente, brasileiros brancos e negros. No caso destes últimos, são quase inexistentes as referências historiográficas tradicionais acerca da sua presença no bairro, entre as quais destaco Castro, Kogurama e Wissenbach.78 
Tal situação leva a pensar sobre o êxito, mesmo que parcial, do ideário europeizante e branqueador desenvolvido ao longo do século XX, cujo legado predominante parece ser a "invisibilidade". A confirmação dessa assertiva é dada pela imprensa da época, em que as referências raciais quase sempre associam a cor dos sujeitos a comportamentos desviantes (traição, embriaguez, agressões etc.), quando não como agente causador, como vítima.

Na arquitetura, de acordo com o trabalho desenvolvido por Lucena, numa linha semelhante àquela de Marzola, ${ }^{79}$

Os calabreses, que foram comprando seus lotes e quintas nas baixadas do Bexiga, projetaram suas residências, esses conhecidos por "capomastri", construtores italianos, que desenhavam o sobrado com a ponta do guarda-chuva em terra batida no chão [...] Surgiram as casas geminadas, a maioria com três a quatro andares, enriquecidas por sacadas e floreiras [...] A arquitetura típica dos italianos foi misturada aos modismos da época. A partir de 1914, as ruas iam sendo calçadas e mostrando fachadas "compoteiras", onde traços neoclássicos se misturavam ao barroco colonial, formando o decantado "estilo macarrônico". 80

Em grande parte praticada, por capomastri não exclusivamente italianos, a edificação das casas do bairro obedeceu antes de tudo à normatização imposta pelo poder público. Por outro lado, distante da uniformidade das "casas operárias", - bairro apresentou uma diversidade de tipologias edilícias que serviram a diferentes camadas sociais, demonstrando a coexistência entre segmentos sociais distintos. Imóveis térreos e sobrados, geminados ou em série, de uso misto ou exclusivo, dão uma textura bastante heterogênea à volumetria da área, que salta aos olhos quando analisamos a iconografia com olhos de ver, sem pré-conceitos e preconceitos.

Pensando a cidade de São Paulo nas primeiras décadas do século XX, a partir de uma perspectiva que leve em conta o fator humano, temos de um lado brasileiros brancos e afrodescendentes (negros e pardos), ambos carregando o ônus de um passado escravista recente que determinava a priori a sua posição na escala social, circunstância agravada pela crença generalizada na superioridade racial e cultural do estrangeiro. De outro lado, temos imigrantes europeus em busca de oportunidades para conquistar, através do trabalho, a estabilidade que thes era negada no local de origem. Nessas circunstâncias, o convívio entre os dois grupos podia significar uma disputa desigual pelas oportunidades de trabalho e pelo espaço, gerando ressentimentos entre todos os lados envolvidos.
79. Lucena (1983); Marzola (1979).

80. Lucena (1983, p. 86 , grifo nosso). 
No longo prazo essa situação só fez ratificar a discriminação, ainda que dissimulada, dos valores atribuídos ao segmento negro da sociedade contemporânea, inclusive àqueles estabelecidos no bairro do Bexiga. Atualmente, embora a presença dos afrodescendentes seja um fato reconhecido, sua importância aparece reduzida cultural e espacialmente: de um lado, porque limitada aos eventos culturais dados pelo calendário festivo da cidade - o Carnaval -; de outro, porque restringe sua presença ao Vale da Saracura, supostamente a única área ocupada por esse segmento social.

Diante desse panorama reducionista, que exclui uns em favor de outros, busquei desmistificar tais estereótipos e identificar a presença tanto de imigrantes como de brasileiros integrantes das camadas médias e baixas da sociedade, para quem o bairro significou não apenas um espaço de moradia, mas também de sobrevivência. 


\title{
REFERÊNCIAS
}

\author{
FONTES MANUSCRITAS
}

AlBUQUERQUE, Fernando de. Planta dos terrenos do Bexiga. São Paulo, 1890. (Arquivo Aguirra, Acervo Museu Paulista).

ALVARÁ E LICENÇA. São Paulo: Secretaria Municipal de Cultura, 1906-1908. Fundo Polícia e Higiene (Arquivo Histórico Municipal).

Boletins De ocorrênCIA. Posto Médico da Assistência Policial. São Paulo: Fundo da Secretaria de Segurança Pública, 1911-1912, 1914-1915, 1925. (Arquivo Público do Estado de São Paulo).

FISCALIZAÇÃO. São Paulo: Secretaria Geral, 1906, PAH 06. (Arquivo Histórico Municipal).

OBRAS PARTICULARES. São Paulo: Fundo Diretoria de Obras, 1906-1923. (Arquivo Histórico Municipal, Secretaria Municipal de Cultura de São Paulo).

FONTES IMPRESSAS

ALMANAK Laemmert. Rio de Janeiro, 1906-1918, 1921-1927, 1931 (Acervo da Hemeroteca Digital da Biblioteca Nacional).

BRASIL. Decreto-Lei $\mathrm{n}^{\circ}$ 4.598, de 20 de agosto de 1942. Dispõe sobre aluguéis de residências e dá outras providências. Diário Oficial da União. Rio de Janeiro, DF, 21 ago. 1942. Seção 1, p. 12897.

JORNAL (do Estado). Imposto do Comércio e Indústria 1933. Distrito da Bella Vista. Orgão Oficial dos Poderes do Estado de São Paulo. Ano 1, n. 130. 1933. Informação disponível em: $<$ http://www.jusbrasil.com.br/diarios/3926582/pg-33(e_outras)-diario-oficial-diario-oficial-doestado-de-sao-paulo-dosp-de-10-06-1933/pdfView>. Acesso em: 17 maio 2015.

O ESTADO DE SÃO PAULO. São Paulo: Acervo Estadão, 1900-1931, 1936, 1938.

SÃO PAUlO (Estado). Decreto $n^{\circ} 233$, de 2 de março de 1894. Estabelece o Código Sanitário. Diário Oficial do Estado, São Paulo, Assembleia Legislativa, 8 mar. 1894. p. 9605. 
SÃO PAULO (Estado). Lei ${ }^{\circ}$ 1.242, de 26 de dezembro de 1910. Cria o Distrito de Paz de Bella Vista, desmembrado do da Consolação, do município da Capital. Diário Oficial do Estado, Assembleia Legislativa, 4 jan. 1911. p. 37.

LIVROS, ARTIGOS E TESES

ALVIM, Zuleika M. F. Brava gente! Os italianos em São Paulo, 1870-1920. 2. ed. São Paulo: Brasiliense, 1986.

AMERICANO, Jorge. São Paulo naquele tempo (1895-1915). 2. ed. São Paulo: Carrenho, 2004.

BARBUY, Heloisa. A Cidade-exposição: comércio e cosmopolitismo em São Paulo, 1860-1914. São Paulo: Edusp, 2006.

BONDUKI, Nabil. Origens da habitação social no Brasil. São Paulo: Estação Liberdade, 1998.

BRESCIANI, Stella; NAXARA, Márcia (Orgs.). Memória e (res)sentimento: indagações sobre uma questão sensível. 2. ed. Campinas: Editora da Unicamp, 2004.

BUENO, Beatriz Siqueira. Tecido urbano e mercado imobiliário em São Paulo: metodologia de estudo com base na Décima Urbana de 1809. Anais do Museu Paulista, São Paulo, v. 13, n. 1, p. 59-97, 2005.

. Aspectos do mercado imobiliário em perspectiva histórica. São Paulo (1908-1950). São Paulo: FAU-USP, 2008.

São Paulo - um novo olhar sobre a história: a evolução do comércio de varejo e as transformações da vida urbana. São Paulo: Via das Artes, 2012.

Escritório técnico Ramos de Azevedo, Severo \& Villares: longevidade, pluralidade e modernidade (1886-1980). Revista CPC, São Paulo, n. 19, p. 194-214, 2015.

BURKE, Peter. História e teoria social. Tradução: Klauss Brandini Gerhardt, Roneide Venâncio Majer e Roberto Ferreira Leal. 2. ed. São Paulo: Editora da Unesp, 2012. 
CAMPOS, Cristina de. O sanitarista, a cidade e o território: a trajetória de Geraldo Horácio de Paula Souza em São Paulo, 1922-1927. Revista do Programa de Pós-Graduação em Arquitetura e Urbanismo da FAU-USP, São Paulo, v. 11, p. 74-89, 2002.

CASTRO, Márcio Sampaio de. Bexiga: um bairro afro-italiano. São Paulo: Annablume, 2008.

DEAECTO, Marisa Midori. Comércio e vida urbana na cidade de São Paulo (1889-1930). São Paulo: Editora Senac, 2002.

EMPRESA PAULISTA DE PLANEJAMENTO METROPOLITANO. Memória urbana: a grande São Paulo até 1940. v. 2. São Paulo: Imprensa Oficial, 2001. p. 97-98. (Arquivo do Estado de São Paulo).

FIGUEIREDO, Betânia G. Barbeiros e cirurgiões: atuação dos práticos ao longo do século XIX. História, Ciências, Saúde-Manguinhos, Rio de Janeiro, v. 6, n. 2, p. 277-291, 1999.

GAUTHIEZ, Bernard. Lyon en 1824-32: un plan de la ville sous forme vecteur d'aprés le cadastre ancien. Géocarrefour, Lyon, v.83, n. 1, 2008. Disponível em: <https://journals. openedition.org/geocarrefour/4542>. Acesso em: 23 nov. 2015.

GAUTHIEZ, Bernard; ZELLER, Olivier. Lyons, the spatial analysis of a city in the 17 th and 18th centuries. Locating and crossing data in a GIS built from written sources. In: RAU, Susanne; SCHÖNHERR, Ekkehard (Eds.). Mapping spatial relations, their perceptions and dynamics, lecture notes in geoinformation and cartography. New York: Springer, 2014. p. 97-118.

GENNARI, Luciana Alem. As casas em série do Brás e da Mooca: um aspecto da constituição da cidade de São Paulo. 2005. 309 f. Dissertação (Mestrado em Arquitetura e Urbanismo) Universidade de São Paulo, São Paulo, 2005.

GONTIER, Bernard. Bexiga. São Paulo: Mundo Impresso, 1990.

GRÜNSPUN, Haim. Anatomia de um bairro: o Bexiga, São Paulo: Cultura, 1979.

HOMEM, Maria Cecília Naclério. Higienópolis: grandeza de um bairro paulistano. 2. ed. rev. e ampl. São Paulo: Edusp, 2011.

KOGURAMA, Paulo. Conflitos do imaginário: a reelaboração das práticas e crenças afrobrasileiras na "Metrópole do Café", 1890-1920. São Paulo: Annablume, 2001. 
LANNA, Ana Lúcia Duarte. O Bexiga e os italianos em São Paulo. In: LANNA, Ana Lúcia Duarte et al. (Orgs.). São Paulo, os estrangeiros e a construção das cidades. São Paulo: Alameda, 2011. p. 117-130.

LEFÈVRE, José Eduardo de Assis. De beco a avenida: a história da Rua São Luiz. São Paulo: Edusp, 2006.

LEMOS, Carlos A. C. Alvenaria burguesa. São Paulo, Nobel: 1985

Casa paulista: história das moradias anteriores ao ecletismo trazido pelo café. São Paulo: Edusp, 1999a.

A República ensina a morar (melhor). São Paulo: Hucitec, 1999 b.

Cozinhas, etc. São Paulo: Perspectiva, 1976.

LEPETIT, Bernard. Por uma nova história urbana. Tradução: Cely Arena. São Paulo: Edusp, 2001.

LUCENA, Célia Toledo. Bixiga, amore mio. São Paulo: Parnatz, 1983.

MALATIAN, Maria Teresa. Memória e identidade entre sapateiros e curtumeiros. Revista Brasileira de História, São Paulo, v. 16, n. 31-32, p. 193-206, 1996.

MARINS, Paulo César Garcez. Um lugar para as elites: os Campos Elíseos de Glette e Nothmann no imaginário urbano de São Paulo. In: LANNA, Ana Lúcia Duarte et al. (Orgs.). São Paulo, os estrangeiros e a construção das cidades. São Paulo: Alameda, 2011. p. 209-244.

MARZOLA, Nádia. Bela Vista: história dos bairros de São Paulo. São Paulo: Prefeitura Municipal, 1979.

MORENO, Julio. Memórias de Armandinho do Bixiga. São Paulo: Editora Senac, 1996.

OLIVEIRA, Maria Luiza F. de. Entre a casa e o armazém: relações sociais e experiência da urbanização - São Paulo, 1850-1900. São Paulo: Alameda, 2005.

PENTEADO, Jacob. Belenzinho, 1910: retrato de uma época. 2. ed. São Paulo: Carrenho; Narrativa Um, 2003.

PEREIRA, Paulo Cesar Xavier. São Paulo: a construção da cidade 1872-1914. São Carlos: RiMa, 2004. 
PLANTA GERAL da cidade de São Paulo. Divisão Cadastral da $2^{\text {a }}$ Secção da Diretoria de Obras e Viação da Prefeitura Municipal. São Paulo: Secretaria Municipal de Desenvolvimento Urbano, 1916. (Acervo Histórico Demográfico do Município de São Paulo).

PLANTA DA CIDADE de São Paulo, mostrando todos os arrabaldes e terrenos arruados. São Paulo, 1924. (Acervo Histórico Demográfico do Município de São Paulo. Secretaria Municipal de Desenvolvimento Urbano).

PLANTA DA CIDADE DE SÃO PAULO e municípios circunvizinhos. São Paulo: Tramway Light Power, 1943. (Acervo do Instituto Geográfico e Cartográfico do Estado de São Paulo).

REIS FILHO, Nestor Goulart. Habitação popular no Brasil: 1880-1920. Cadernos de Pesquisa do LAP, São Paulo, n. 2, 1994 a.

. São Paulo e outras cidades: produção social e degradação dos espaços urbanos. São Paulo: Hucitec, 1994 b.

Quadro da arquitetura no Brasil. 10. ed. São Paulo: Perspectiva, $2004 a$.

São Paulo: Vila, cidade e metrópole. São Paulo: Prefeitura do Município de São Paulo, 2004b.

ROCHE, Daniel. O povo de Paris: ensaio sobre a cultura popular no século XVIII. São Paulo: Edusp, 2004.

ROLNIK, Raquel. A Cidade e a lei: legislação, política urbana e territórios na cidade de São Paulo. 3. ed. São Paulo: Fapesp, 2003.

SANTOS, Carlos José Ferreira dos. Nem tudo era italiano: São Paulo e pobreza (1890-1915). São Paulo: Annablume, 1998.

SALLES, Maria do Rosário R.; SANTOS, Luís A. de Castro. Imigração e médicos italianos em São Paulo na Primeira República. Estudos de Sociologia, Araraquara, v. 6, n. 10, p. 64-95, 2001.

SCHNECK, Sheila. Formação do bairro do Bexiga em São Paulo: loteadores, proprietários, construtores, tipologias edilícias e usuários (1881-1913). 2010. 283 f. Dissertação (Mestrado em Arquitetura e Urbanismo) - Universidade de São Paulo, São Paulo, 2010.

SEVCENKO, Nicolau. Orfeu extático na metrópole: São Paulo, sociedade e cultura nos frementes anos 20. São Paulo: Companhia das Letras, 1992. 
SOCIETÁ ANÔNIMA DE RILEVAMENTI AEROFOTOGRAMMETRICI. Mappa topographico do município de São Paulo. São Paulo, 1930. fl. 51. (Arquivo Histórico Municipal, Secretaria Municipal de Cultura, Departamento do Patrimônio Histórico).

TELAROLLI JÚNIOR, Rodolpho. Poder e saúde: a República, a febre amarela e a formação dos serviços sanitários no Estado de São Paulo. 1993. 483 f. Tese (Doutorado em Ciências Médicas) - Universidade Estadual de Campinas, Campinas, 1993.

TOLEDO, Benedito Lima de. São Paulo: três cidades em um século. São Paulo: Duas Cidades, 1981.

WISSENBACH, Maria Cristina Cortez. Sonhos africanos, vivências ladinas: escravos e forros no município de São Paulo - 1850-1880. 1989. 195 f. Dissertação (Mestrado em História Social) - Universidade de São Paulo, São Paulo, 1989.

Artigo apresentado em 30/10/2017. Aprovado em 22/06/2018.

\section{(cc) BY}

